\title{
Out-of-School Child Entering Sports Field
}

\author{
Di Zhang
}

\section{Interview with Dan Cao's Mother}

Dan Cao, male, born on January 1, 1983. The only child in his family. Grade IV intellectual disability. Admitted into the Sunshine Home in Shanghai's Hongkou District, 2005.

Interviewee: Ms. Zengdi Wang (Dan Cao's mother)

Interviewer and writer: Di Zhang

Interview dates: November 4 and December 23, 2016

Interview place: Cao's home

\section{Weak and Sick Ever Since Childhood}

Cao's mother: With a head of long and curly hair, my son was born a pretty baby, very good looking by Shanghainese standards. The doctor scored him 10 and there was no trace of Down syndrome... at all. Yeah, he was indeed the apple of everyone's eye in the family.

By the time he was 2 years old, I found that he wasn't able to control his bladder. While he was telling me "Mom, I want to pee," he'd already peed. We visited almost every hospital in Shanghai about it, only to be told everything was okay because doctors saw nothing wrong with it.

This lasted until he went to kindergarten (sobbing). He still wasn't able to control his bladder. While he was telling the teacher "I want to pee," his pants were already wet. The teachers demanded to see me every day and they would rebuke me," What's wrong? He's no longer a baby, but he always leaks as soon as he wants to. He is rotting our floor... No way! We cannot accept him if he continues like this!" I had no choice but to take him home.

This problem persisted until he went to school, starting at the age of seven. As soon as he shouted, "I want to pee," he'd peed. He was beaten numerous times for

D. Zhang $(\varangle)$

East China Normal University, 3663 Zhongshan Bei Ro., Shanghai 200062, China 
this. Sometimes I thought he was just too occupied with playing, so he forgot to go to the toilet. However, later I found out that he really had trouble with it.

Why do I say so? Well, he had a lot of urine even while sleeping at night. We took him to the doctors and were told not to let him drink water after ten at night. I questioned, "How can we not allow such a little kid to drink water?" According to the doctors, there should be no water for him after ten at night, even in summer. Well, this was impossible for us to follow as parents. While sleeping at night, he would become restless if he needed to pee. The doctors' opinions were that we let him pee too frequently, so he had very short intervals between urination. They advised us not to interfere with his time to pee. I tried but then he just peed involuntarily. If you told him, "Son, get up and pee," he would empty his tank immediately. If you let things take their natural course, however, he always ended up wetting the bed. After all, he was so young and therefore a heavy sleeper!

We have visited all of the hospitals in Shanghai, big and small, countless times about this. Both my husband and I have spent as much as we can earn. They say dried lychees are effective for this problem, so we made him eat probably dozens of pounds of dried lychees each year, even up until today. I have tried everything that is said to be effective, be it food, nutritional supplements, popular folk prescriptions, and even acupuncture, but all in vain. My son has indeed had enough of them.

Later, we turned to my husband's cousin, a medical graduate, for help. "I am sorry I don't know how to treat this," she said. "However, I do know a director at Shanghai Children's Hospital. He generally would only see a limited number of patients, but I can call him to see, if that would help?" So, she managed to make an appointment for us with that doctor. My husband and I took our son to him. Oh, the doctor was already very old. It was really not easy for him to continue seeing patients of special needs. After diagnosis, the doctor said, "Take it easy. I will prescribe to you some TCM for a period of 3 months. I assure you he will be fine after taking the medicine."

Well, that was 20 years ago, and it cost us over 8 yuan per week for the prescribed TCM. It was really very expensive for us. You see, my husband and I literally spent all the money we had on him. Sometimes, we didn't even have any money left for meals, and I had to ask my parents to help me out (giggles). I would tell them that we were starving for the sake of this kid. My parents were really helpful. They would say, "Then send the boy to us instead of hiring babysitters. Let us take care of him." I was reluctant to do so due to concerns of their age and health. How could I ask for more when they already supported me financially? Anyway, when I visited them, I always received money from them, sometimes 50 yuan, and sometimes 100 yuan, which was almost a fortune in those days.

So, we fed him on TCM for 3 months, but it had no effect at all. Then we asked the aunt's daughter to contact that senior doctor again. "How was it," he asked, "Is the boy okay now after taking the medicine for 3 months?" I replied, "To be honest, I'm sorry to say that there has been no change at all." Hearing this, this old professor was very surprised. His immediate thought after that was: "Alright, you don't need to tell me more. Let me make a call to arrange an X-ray for your son. He most definitely has a problem with his spine." How could it be, I wondered. Although my son had never taken an X-ray for his spine, we had him take a bone X-ray for the lower part 
of his body when he was young. The doctor, however, was very certain, because he had seen another kid with the same problem. So he helped us get in touch with the director in charge of radiology at the department of pediatrics.

The director told me that he would first prescribe some laxatives for my son to take after 10 the night before taking the X-ray, so as to empty his bowels. I asked, "Will he get the runs during the night? I need to get myself prepared for that." According to the director, it wouldn't be as bad as that; generally speaking, the bowels would be emptied after going to the toilet once or twice, and that's why he recommended taking the laxative after 10 p.m. I didn't listen to him. I still waited until my son woke up from his sleep after midnight to let him take the pill. Then he had loose bowels (giggles) throughout the rest of the night... Since the doctor said it wouldn't be that bad, I simply wrapped him up with a few large towels. However, this turned out to be a bad idea, because his bowels were running all the time and it even got our quilt dirty (giggles). Being very sensitive to all kinds of medicine, his bowels kept running till twilight. I said to my husband, "It's already 3 a.m. now, we should get up. We have no quilt to use anyway (giggles)." We left our last quilt on our son and then got up. My husband asked me what I was going to do. I said laundry. There were so many things to wash and there was no way of getting around it.

I told my husband to boil some water, the more the better, because all the stuff, being so smelly, had to first be soaked in boiled water. My husband thought I was being funny. According to him, why bother, simply washing them would suffice. I said if that was the case, I would rather throw them away (giggles), so no way.

In the morning, we took him for the X-ray. The doctor told us that the result would be ready in $2 \mathrm{~h}$ and an appointment was made with that old professor. The professor assured us that he would wait for us because he knew we had such a difficult time. Indeed, at that time we had tears in our eyes all day long (giggles).

Two hours later, we fetched the X-ray film to give to the professor. Just as he expected, there was a crack on my son's spine, which was a congenital problem and the reason behind his inability to control his bladder. Whenever he felt like peeing, he would leak instantly. The professor told us not to beat our son for this, because the kid himself also suffered. Just think of the countless Western medicines and TCM he had taken. I asked the professor what to do. According to him, there was no treatment. We could only let things take their natural course and wait for him to gradually develop. If the spine is sealed up once he becomes fully developed, the problem will be gone; otherwise, it will remain throughout his life. The professor recommended us to give our son more nutrition, so that he could start his physical development earlier and have the spine crack sealed up. Well, things really turned better later. When he turned nine, the problem suddenly disappeared.

Another problem with him was that he dared not walk by himself even when he was 2 years old. He only dared to walk when there was something for him to lean on, but not independently. I was at a loss, so we took him to Xinhua Hospital and he also took an X-ray. When he was taking the X-ray, we were very afraid, because we had seen many kids unable to walk owing to bone problems in their legs. My husband and I were really anxious to know what his problem was. If he was like those kids, his entire lower body would need casts. A week later, the X-ray result 
came out. The doctor told us that our son did not have any bone problems. "Then how come he could not walk?" we asked. According to the doctor, this was because our son was timid, so we had to make him braver. I wondered why he would be so timid. The doctor recommended that we let him walk along the edge of supportive objects. "Well, he does walk beside the bed or the sofa," I said. "He just refuses to walk independently." At that time, he was two and a half years old.

My employer told me that I had to go back to work because never ever had anyone enjoyed such a long maternity leave. My husband was a section chief in our workplace. I found it too embarrassing to tell others that my son wasn't able to walk yet. I dared not mention it.

I worked on and off, going to work one day and taking sick leave the next day, because I had no one to help me take care of my son. At that time, my husband's grandfather was already very old and very ill. He had no one to take care of him but my mother-in-law. Then I was left without anyone at home to help take care of my son. The only choice for me was to hire a woman living across the street to be the babysitter. I asked her to help whenever I was not allowed to take sick leave and I told her not to worry about being underpaid. If I remember correctly, the cost of babysitting at that time was already 300 yuan. Literally I was paying my entire salary to her. Even so, it was like begging her to babysit my son, because no one was interested.

When my son was in someone else's hands, he would not get as much care as from his mom (giggles). The babysitter would simply put him beside the wall. I was told after I took my son back home that the babysitter left him alone standing beside the wall, and she told him to either walk over by himself or whatever. Somehow, this forced my son to walk independently (giggles). Not bad. That babysitter said to me, "He would never be able to walk independently if he was in your hands. See, now I have taught your son to walk." Oh, I was really very grateful to her and I bought her gifts. "Thank you so much! He would never be willing to walk independently if he had me at his side," I said to her.

When he turned 4 years old, my employer did not allow me to take sick leave anymore, or the sick leave would be counted cumulatively as long-term sick leave. What should I do? What's more, that babysitter quit due to her mother's health issues. According to her, she could not babysit for me any longer no matter how much more I was willing to pay her. Then I turned to an old lady living on the first floor of our apartment building for help.

At the age of 18, Dan Cao underwent surgery. He had been suffering from serious cerebral hypoxia, so my brother managed to find an expert overseas, who worked together with Xinhua Hospital on transplanting omentum into my son's brain. This would do good for his brain development afterwards. If there's a serious lack of oxygen to your brain, you would finally lose consciousness, and as a result, you would totally lose the ability to look after yourself. The surgery was costly. We spent hundreds of thousands of yuan on it.

According to that expert, Dan Cao seemed to have had meningitis when he was 2 or 3 years old. This sounded impossible to me. I brought him up by myself, so I am the person who's most clear about whether he had meningitis before or not. "Why 
do we suspect that he had meningitis before?" The expert explained, "His vertex was covered with a layer of scab, just like the scab we would see forming on a cut finger. Such a cover on the vertex leads to insufficient supply of blood to the brain. We have now torn off this cover." According to the expert, this is typical among people who have had meningitis. I told him, however, that I was personally attending to my son when he was 2 or 3 years old, and never ever did I find him running a high fever. I discussed this matter with the expert and asked him if high fever was a symptom of meningitis. He said yes. Anyway, they were of the opinion that he had meningitis before.

Q: So it could not be determined whether it is congenital or acquired?

Cao's mother: Exactly. Not even to this day.

After the surgery, he has seemed to be faring well, able to do some simple things on his own. To be frank, it might not have been possible for him to be admitted into the Sunshine Home, but now he is, and he is able to do some simple things.

\section{Out of Touch with Relatives From the Father's Side}

Cao's mother: My husband is the only son in his family. The rest of the siblings are all sisters, older or younger. Therefore, when our son was born, he was the apple of everyone's eye in the family. At that time, his great grandfather was still alive, over 90 years old. He particularly travelled over from Ningbo, in high spirits, to see his great grandson. Everyone was so happy.

Q: When he was diagnosed with the illness, was your first reaction to conceal the fact or reveal it directly to your relatives and friends for help?

Cao's mother: There's no way to conceal it. We never tried to hide it from our relatives. As for help, however, that was out of the question. His aunts panicked upon finding out. They were afraid to see him. It may not sound nice, but they avoided him like the plague.

Questions: How did the other family members feel?

Cao's mother: Of course, they felt depressed.

His grandparents, especially his grandfather, were very fond of him at first. When he was a newborn, he often had his days and nights reversed, sleeping during the day and awake at night craving attention. I should say it was always his grandfather who got up to pick him up and hold him in his arms.

As a matter of fact, before he turned 2 years old, he had always been in his grandfather's arms. He was really pampered. Whenever his grandfather received any bonus gifts from his workplace, he would give them away to my son. Remember my son could not control his bladder when he was young? Knowing that dried lychees would be effective for this, his grandfather would buy a few pounds every month for him.

However, after learning that his grandson had intellectual disability, his grandfather has been avoiding us for almost a score of years. His grandfather is still alive, but he just refuses to be in touch with us. So do my son's aunts. We were not even informed of the weddings of their sons or daughters. They keep us out of the loop because they don't want to see Dan Cao. 
At first, I myself also... seemed to be unable to come out of the shadows. How unfortunate it is to have a son like that. Later, however, I came to know more people, and I have always been encouraged to face the reality: "It is destiny that brought this kid to your house. There must be a bond between you and him. You care so much about him after all."

Q: Have you ever thought about having another child?

Cao's mother: In fact, my father and mother wanted me to do so badly. At that time, they kept persuading me: "Have one more kid, not for your own sake, but for the sake of Dan Cao." I told them that I would not be able to handle it, because I was already tied up with this kid... How could I manage to have one more? I could not afford it, whether financially or energy-wise. My parents offered to bring up Dan Cao for me so that I would only need to take care of the second kid. I asked what if the second one still had problems? They doubted we would be so unfortunate. Anyway, I was not willing to have one more kid, neither was my husband. As a result, my father-in-law was not happy with me. My parents-in-law refused to stay in touch with us just because of this matter. They did not talk to us, nor could they understand us.

Q: So you are afraid that the next child would still...

Cao's mother: Have intellectual disability.

Q: That's why you don't want another child?

Cao's mother: Yeah. Besides, here are some more of my husband's considerations: It would be great if the next kid was a healthy one, but then you would spend all your energy on him or her, in addition to expenses on education. Dan Cao would then be neglected. If the next kid still had problems, that would mean lifelong suffering for us. Well, let us resign ourselves to Dan Cao, the one and only kid of ours, and let us treat him well. My husband is really a very good man. He decided that we would not have any more kids and we would just be responsible for Dan Cao, taking good care of him. I asked, "I feel pressure from the way your parents treat us now that we've decided not to have another child, what shall I do?" He answered, "You don't need to care about them. Why should we have another kid just because they want us to? Dan Cao is so sick. Why haven't they helped us for even 1 day, instead holding Dan Cao in such contempt?" My mother-in-law is okay, but my father-in-law really turned his nose up at Dan Cao. He seemed to be utterly disgusted at Dan Cao's presence...

Q: They don't understand you, do they?

Cao's mother: Right, they do not understand. They questioned why we would treat such a kid so well.

None of Dan Cao's aunts could understand us. At that time, we wanted to improve our housing condition. After all, Dan Cao's father had worked in Xiamen for more than 10 years, so we had saved some money. My brother told us, "There is a unit in European Garden ${ }^{1}$ at a very good price. I know their boss. Are you interested?" Dan Cao's aunts suggested that after we bought the new house, Dan Cao's grandfather could live with us. "How about his own house then?" I asked. One of the aunts answered, "It is to be divided among us, and he is to live with you." "Why am I

\footnotetext{
${ }^{1}$ Name of a residential community in Shanghai.
} 
supposed to do that?" I said. "I have a disabled child to take care of, and you want me to take care of his old grandpa as well?" We felt it so unfair that we did not buy the new house.

Later, my husband's eldest sister was entitled to my father-in-law's house, and my father-in-law lived with her. I said, "Fine. Since you have done this, I won't ask for anything from you." Now she has sent my father-in-law to a senior care center, but my father-in-law has kept calling my husband to bring him home. My husband said, "You want me to bring you home after you've given away your property? I only have such little space in my house." I told my husband to visit his father (giggles). After all, his father was already over 90 years old. My husband replied, "For what? He didn't even want his grandson. More than 10 years have passed and never ever has there been a phone call to us."

Dan Cao has an aunt whose work is within 5 min' walk from our house, but (she has never visited us). On very hot days when the temperature was as high as 40 degrees, if I went to work, Dan Cao would spend his time alone at home, in the room at the back of the house... (tears) In the past, my husband was sent to work in Xiamen for more than 10 years and I took care of Dan Cao all by myself. Dan Cao's aunts never come to see him.

When I was at work, I couldn't help but worry whether my son would have heat stroke on such hot days... you know the front part of our house has a rather high ceiling and good ventilation, while the room at the back is very small, only 9.8 square meters, and it's very stuffy and hot. Oh, what could we do about it?! I couldn't take care of Dan Cao's lunch, either. Therefore, I told my husband to install a pull switch on the rice cooker. You know every morning after I cooked the rice, I could not unplug the cooker, otherwise the rice would be cold by lunchtime. I told Dan Cao, "I will cook the rice for you every morning and keep it warm. After lunch, just pull the switch. Do not touch any other electrical devices. I'm also going to set an alarm clock for you. After you get up in the morning, wash your face, brush your teeth, and eat breakfast. Then wait until the alarm clock rings to have your lunch." He said yes, but he did not quite understand. Sometimes he got up at eight in the morning and had his breakfast. At nine o'clock, he felt a long time had passed, so he ate his lunch. Then he would not have supper until around half past seven in the evening after I got home (sobbing).

Questions: Do your parents-in-law live far away?

Cao's mother: We used to live together. My father-in-law was affected by the Cultural Revolution. Later, thanks to policy implementation, he was allotted an apartment in Yunguang Community and they moved there.

Q: Has Dan Cao ever been to his grandparents' house?

Cao's mother: Yes. I often took him to visit them when my husband worked in Xiamen. Sometimes they would call us saying that Grandma was not feeling well, and I would take Dan Cao to visit them on such occasions as well.

When my father-in-law needed heart surgery, Dan Cao was about to receive the omentum transplant. Dan Cao is certainly not a smart guy, but it seems sometimes he could firmly remember things that he was not supposed to remember. While at the hospital, he kept the doctor's words in mind. The doctor told me that to perform 
four surgeries at the same time would involve fatal risks. He heard everything. Then he said to me, "Mom, I may die. The doctor said I might not get out of the surgeries alive."

I told him to stop talking nonsense while he said, "I'm serious. I heard the doctor's words. It is a big operation." I said, "Take it easy. It is just an operation to make you smart and there will be experts from abroad! Take it easy. Your uncle is even going to send people from the TV station to videotape it, and he'll be in the operating room, too. Take it easy." At that time, my brother worked at the TV station, and Dan Cao's surgery was indeed a big one, to be jointly performed by Xinhua Hospital and foreign experts. The TV station planned to videotape it and broadcast it if it turned out to be successful.

He said: "I can't... I know there is danger involved in the operation. The doctor has said so. I heard his words. Please call my grandfather to see me, so that I can see him, too. Maybe this will be the last time for me to see him." Oh, hearing this, I could not hold back my tears. I said, "You will be fine. Stop talking nonsense. You know your mom believes in Buddha. Mama has prayed to the Buddha and the Buddha has given you his blessings."

He seemed to be missing his grandfather so much, so I said to my husband, "Call your dad, and let us bring him over by taxi or my sister can pick him up." Dan Cao's grandfather just refused to come. He refused all the time, saying that he would not go to see Dan Cao.

I could not tell my son bluntly that his grandfather didn't want to come, so I said, "Your grandpa is old and not very well." Want to know Dan Cao's reply? He said, "Grandpa is old, so is Grandma (on mother's side). How come she comes every day?" I said, "Grandpa is not very well." We could only explain it to him in this way. We could not tell him that his grandfather refused to see him.

I was actually angered by the fact that Dan Cao's grandfather refused to see him in spite of Dan Cao's earnest requests.

Q: So you rarely visited his grandparents afterwards?

Cao's mother: Very rarely.

Shortly after Dan Cao had his surgery, my mother-in-law fell ill. She was diagnosed with colon cancer in the beginning, and later it spread to the liver. I had been taking care of her since she became sick. My mother-in-law was a nice person, very honest and docile, while my father-in-law was rather tough. Although she had four daughters, none of them would take care of her, because they all regarded her as useless. Seeing that she was sick with no one to attend to her, I decided to take care of her. The doctors in Shanghai General Hospital commented to my mother-in-law, "Your daughter is really good, and those four daughters-in-law seem to be quite mean." They found it hard to believe when my mother-in-law told them it was just the opposite. I accompanied my mother-in-law for 7 days and nights at the hospital after she had the surgery, and finally I had a swollen face. When my younger sister came to see me, she complained: "You are crazy! She has so many daughters, so why you? She's not your mother." I said, "Well, don't look at things this way. I regard my mother-in-law as my mother, too. My mother and his mother mean the same to me. My husband is such a nice man. I shan't treat his mother unfairly, shall I?" 
Q: Did your mother-in-law ever come to see Dan Cao?

Cao's mother: Rarely. My mother-in-law was a timid person. If she came frequently, she would be told off by my father-in-law. So, she didn't dare come. She did come secretly, though, but she would rush back home after a very brief stay to prepare a meal for my father-in-law, who is now over 90 years old. He received university education, which was quite something back in his time. Indeed, he had a very feudal mindset.

Q: Does your husband stay in touch with them?

Cao's mother: They will inform him if anything occurs.

Q: You rarely visit them, but sometimes they will ask you to come over?

Cao's mother: Right. They would call me to come over. You know my motherin-law was admitted into Shanghai General Hospital, which is just across the street from our house, so they wanted me to take care of her. I had to do that. I believe the Buddha is watching. Anyway, I make sure that I do what I am supposed to do as a daughter-in-law.

Finally, my mother-in-law passed away. My father-in-law then had heart bypass surgery. He demanded I take Dan Cao along and take care of him. In fact, Dan Cao was so young at time, and he also had surgery only a few months before. I said, "My husband has three sisters, all of whom are homemakers. Why can't they do the job? I work every other day and on days I work, I ask my mother to come over and take care of my son. Now you tell me to take care of you. Two of your daughters are retired. You don't turn to your daughters for help, but to me, the daughter-in-law?" Daughters would be in a better position to do such things than in-laws. It's really awkward for a woman to attend to her father-in-law. If my father-in-law is already very old and oblivious, it's okay for me to help him take a bath or clean his body. Now that he is clear-headed, how could you ask a daughter-in-law to do those things, especially when her husband is away? Don't you agree? However, my father-in-law insisted on me taking care of him because I am a meticulous caregiver. I offered to hire him a nanny at my expense, but he rejected the idea. He just wanted me to take care of him. According to my husband, I had no choice but to obey. I had no choice indeed, so I took Dan Cao along to go and take care of him.

Sometimes, I said jokingly to my husband, "Cao, your family is simply treating me as a nanny (giggles) rather than a family member. They asked me to take leave from work to take care of your father while you were away from Shanghai. Actually, I didn't even have enough time to take care of Dan Cao. Am I right?"

Q: That's really tough. How long did it last?

Cao's mother: Three months, and Dan Cao went there, too. On my workdays, Dan Cao stayed in his grandfather's house. I made a deal with my father-in-law that I had to go to work. I would take care of him on days off work, and his daughters would take care of him on the other days. Those days, no matter who was taking care of him, I would get up at four o'clock in the morning to prepare the meals before going to work, so that they would not need to be cooked. Even so, they were still very mean to Dan Cao.

Q: What did they do? 
Cao's mother: At that time, Dan Cao was still taking medicine for brain rehabilitation. I told them that I would have Dan Cao take the medicine in the morning and asked them to remind him to take the medicine again at midday, otherwise he would forget to do so. They simply needed to say, "Dan Cao, take your medicine after you've had your lunch." Dan Cao could take his medicine by himself and he knew how much to take. I've already taught him these things. I would have Dan Cao take the medicine again in the evening after I return from work. My father-in-law then said, "He's already over 20. Can't he take the medicine himself? Why do we have to remind him?" I told him that Dan Cao indeed would not remember, otherwise I wouldn't have asked them to help me remind him. I said a simple reminding would do. Yet he refused, claiming that was not their business.

Anger was burning in my heart at their unfair treatment of Dan Cao. After taking care of my father-in-law for 3 months, I decided to quit. Nevertheless, when my husband returned home during the National Day holiday, I still encouraged him to pay a visit to his father with Dan Cao. I said, "After all, he's your father, who gave birth to you and brought you up. I wouldn't mind if you do that. I am an in-law, an outsider. Go and take Dan Cao along. I'll get the fruit and nutritional supplements ready. It has just been a couple of months since your father had the major heart surgery. Go and see him."

After my son returned from that visit, he told me, "Mom, it was very strange. Obviously, Auntie still has cooking oil at home, but she asked Dad to buy a bucket of oil for her. She has been asking Dad to buy this and that for her. As a matter of fact, I can tell that she has everything in her house." I told him to stay away from us adults' business. I said, "Your dad hasn't been home for several months. It's okay for him to buy things for your old grandpa." My son said, "But Grandpa has a pension to live on. You've been toiling to take care of me, but even so, you don't tell Dad to buy things for you." I answered, "I can buy things myself and I am strong enough to carry them, but your grandpa is too old to carry things himself." "They are taking advantage of us," my son retorted. "Don't say that," I told him, "Who's going to take advantage of us? No one. We are young and we are not afraid of being taken advantage of."

Anyway, my husband was not in a good mood that day after he returned from his visit to his father, but he said nothing to me. Later when he was about to travel back to work, he told me, "You are set free now. They will not trouble us anymore." I asked why and he told me his father's words: "This is your last visit to me. You don't need to come any more. I don't want to see you, and I don't want to see Dan Cao." My husband has never gone to see his father ever since, and neither has Dan Cao.

Well, 11 years have passed. Later, his father sold his house and lived with his eldest daughter. In fact, my husband was making investments on the stock market at that time and he asked his father to buy and sell stocks on his behalf. Since the stocks were under my husband's name, his father could only do transactions but not withdraw money from the account. One day, his father had the documents related with the stock account sent back to us by express delivery, saying that he was not going to do transactions for us anymore. I called my husband. He told me to take 
them and said that he would deal with them when he came back. A few days later, a former classmate of my husband's, who was on very good terms with my husband and worked at a notary office, gave me a phone call, informing me that my fatherin-law had gone through notarization procedures to put his house under the name of his eldest daughter. I said, "Fine, as long as she treats him well. We can do without his property. We are not greedy and we rely on ourselves."

My husband has a sister who's been out of touch with us for more than 10 years, but now we've started to see each other again. She lives in Pudong. Four years ago, she took the initiative to visit us with gifts, and she apologized, "I am sorry about what I did to you in the past. I should not look down on you when your family is already in a pitiable condition." I replied very politely, "It is okay and we are fine. To us, Dan Cao is no different from any other kids, so you don't need to say that." Later, she invited us to her son's wedding. I did not want to attend, so I gave her 5,000 yuan as gift money instead. I don't mind restoring our relationship with them, but I would not take the initiative to have anything to do with them, either. Actually, it was no big deal that we started to see each other again. We would visit each other once during the Spring Festival and call each other once or twice on a monthly basis. To be frank, she had ulterior motives. Last year, she intended to change her registered residence into our address. You know she's already over 60 years old. Why did she want to do so? For the sake of our house. She had given her house to her son after he got married. If she registers her residence as our address, after we become old, she could take advantage of Dan Cao's ignorance to possess our house. She will definitely not treat my son well. She will send him to a senior care center. I would rather give away my house to the government because the government will take care of Dan Cao. I told her, "I cannot let you register at our address." Currently, my family is living a peaceful life with three of us registered under one household. I told my husband very calmly, "If that needs to be done, let us divorce first, with a notarized arrangement that the rear room of nine square meters at the back would belong to you and the front room of twenty square meters belong to me, so that Dan Cao and I will have a place to live. Then I would not interfere if you want to help her register her residence in our house. I will not put Dan Cao in their hands. I will definitely raise him by myself."

Last year, she called us unexpectedly, informing us that the eldest sister had sent my father-in-law to the senior care center. My husband readily accepted the fact. According to her, the eldest sister's husband had been quarrelling with my father-inlaw all the time, and the reason was that they lost their patience taking care of him. I questioned, "But Dad is not confined to bed. Although he's over 90 years old, he is still well and able to take care of himself." She said, "They are tired of him at home anyway, so they sent him away."

My father-in-law has mentioned to her several times that he is missing us. I said, "What he really misses is not us, but the fact that I could take care of him. When I was attending to him, I helped him take a bath every day and I also cleaned his house. Now he has realized that there's no one to take care of him, so he wants me to do it again." Later, I told my husband to visit his father at the senior care center. My husband refused. I said, "Why, he's your father after all. Go and see him." My 
husband told me, "If I go to see him, he will definitely want to come back with me, and then you will have to take care of him. Forget about it. There's no point in doing so. You just make sure that you take good care of Dan Dan."

Q: You are not in contact with relatives from your husband's side. How about relatives from your own side?

Cao's mother: We are on very good terms. My siblings and I are very affectionate towards each other. I have an elder brother, a younger brother, and a younger sister, who all give us a lot of care and treat my son very well. My sister buys clothes and other gifts for Dan Cao every year. This year, she went to Australia, but she got new winter clothes ready for Dan Cao before she left. I asked, "Why did you do that, for fun?" She said, "Well, I am just used to doing it. These are for his New Year clothes." The nutritional supplements Dan Cao is taking now are also brought back by my sister from Australia. Since my parents have passed away, we have now inherited the new house allotted by the government as a result of the relocation of their previous residence in Huangpu District. I actually told my siblings, "I do not care. Divide the property as you like" My brother said, however, "Take it. You deserve it." Some families will fight over these kinds of things, but not us.

My sister, being a businesswoman, is very busy. Therefore, her child lived with us, such as during vacations, when she was young. Dan Cao spent a lot of time in his childhood with my sister's daughter, and he did not seem to be too different from her. We also bought her a lot of toys such as building blocks and toy cars. They had no problem playing together.

When my sister's child came over, I would tell her, "Fruits are washed and ready for you kids to eat. When it's time for lunch, please keep an eye on Dan Cao. Make sure that he does not eat too much. Dan Cao is heavily overweight, so his diet has to be controlled." She did an excellent job. My sister's child is actually 6 or 7 years younger than Dan Cao, but she was able to take care of him.

Q: Didn't your employer know Dan Cao's condition? What was the consideration behind your concealment of the fact?

Cao's mother: Indeed, I didn't tell them. Why? My husband was a section chief in the factory, not a high-level position but still an important one. In charge of the production line, he had to make sure that production tasks would be completed on time, otherwise he would be blamed by his boss. It was impossible for him to make everyone happy. That was why we decided to keep our situation a secret to avoid being mocked at work. My husband was advised to join the Communist Party, but we declined. However, they kept persuading my husband, so he finally submitted the application letter. At that time, you know, there would be a family visit for investigation purposes if you applied to join the Party.

Q: So you were afraid of such a visit, weren't you?

Cao's mother: They found it out when they visited us. Dan Cao was about 7 or 8 years old at the time. The visitors from the factory asked, "Why didn't you tell us?" I said, "It's not worth mentioning. I haven't even told my best friends. None of my colleagues know." There was a rather close friend of mine who once dropped into my house without notice. I was sitting with my son talking to him. She could tell after a while that it was not like communication with a normal kid, so she asked if 
my son had a problem with his intelligence. I replied, "Why? No." She complained, "You are trying to hide it, even from me." I then said, "What's the point of telling the world?" A few days ago, she called me saying that she wanted to come over to see my son. I said, "For what? He is no different from your daughter, two eyes, one nose, and one mouth. There's nothing special about him to see." She said, "Your son is a good boy. We would like to see him and spend time with him." I replied, "There's nothing special about him to see. He is fine." Anyway, now some people know the condition of my son, hmm, but it was after we retired.

Q: So you rather rejected the idea of talking with her about this topic?

Cao's mother: Right. I didn't want my colleagues to know. At that time, my husband was working outside Shanghai. I never attended activities such as dinners at my workplace. I even gave away my rewards like free trips when I was elected a model worker.

Q: After your situation was known at your workplace, did you get any help?

Cao's mother: No. At that time, my workplace was not doing well in business. The opportunity of receiving help was gone. There was a co-worker in my workshop that was said to have a kid in a similar situation. According to our leaders, he received subsidies every year. I said to them, "Would he make a fortune out of such subsidies? Apart from the fact that I don't want you to subsidize me."

\section{Barred From School in Spite of Every Possible Effort}

Q: What's the consideration behind your sending your son to the kindergarten for normal kids?

Cao's mother: It was time to enroll kids and my son didn't seem that intellectually disabled at the time. He was enrolled through the normal procedure but was rejected by the school half a year later. He was also enrolled in elementary school through the normal procedure. The teacher visited us first and interviewed him. He answered the questions very well.

Q: Did he like going to kindergarten? Did he refuse to go the next day?

Cao's mother: At first, he liked going, to elementary school as well. Later, however, after he was scolded and beaten by teachers, he refused to go.

In fact, when he was in kindergarten, we found that he might have a problem with his intelligence, but we were not aware that it was so serious. After he studied at the elementary school for normal kids for a month, the teacher told us that he could not write. He could manage to answer (questions), but he could not write at all. His brain just could not control his hands. Elementary schools usually teach Chinese phonetic alphabets in the beginning. The teacher advised us, "Teach him at home. You son is still not able to write the phonetic alphabet." I said, "We've been teaching him all the time at home." He was even beaten or scolded for that. Of course, we also gave him a lot of instructions on how to write. Every day, we held his hand (teach him to write) for 1 or $2 \mathrm{~h}$, but he just couldn't do it. Sometimes he also hated himself, and he would complain that his hand felt sore from being held to write for so long. I said, "Then you try to write on your own." He said, "I simply cannot do it!" He is like this even today. His brain cannot control his hands. 
Later, he leaked one day at school and was scolded by the teacher. After that, he was no longer willing to go to school. I said, "You still have to go to school." He said, "He called me stupid, an idiot, a fool. The classmates also said I was stupid, too stupid. I do not want to go to school." I frowned at his words, "If the teacher labeled you this way, you have to try harder." Later, the teacher advised us to drop out of school. He said, "Your son cannot learn, nor can he control his bladder, and he cannot even write. Don't you think he's dragging our class behind?" The teacher told us to make him take an IQ test. Well, I remember he got only 57 points, while the minimum passing score is $60 .^{2}$

According to the teacher, "You should try the schools for low-intelligence students. Such schools recruit students once every 2 years, not on an annual basis. You just missed their recruitment this year, so you won't get enrolled this year. Next year there won't be recruitment, so you have to wait until the year after next to register."

Q: The teacher even scolded and beat him?

Cao's mother: Right. Beat him and pinched him. He sometimes said to me, "Mom, I got this bruise because the teacher pinched me..." We would go to ask the teacher, but he would not admit it. He would say, "No, we never (beat him). Perhaps he got it by hitting something somewhere. How could it be that we pinched him?"

Once there was a kid nearby, who is still on very good terms with Dan Cao today. He told us that they saw the teacher pinch Dan Cao. You could do nothing about it, except burst into tears. You could do nothing... Sometimes we felt it so heart-wrenching that we let him drop out of the school to avoid being bullied.

Q: How did he get along with that classmate who was on rather good terms with him?

Cao's mother: Now we do not see him often, but at that time he often came over to see Dan Cao. He did care about Dan Cao. He said that he was a very good and friendly guy. He is still very friendly to Dan Cao today when they meet, but we will not disturb him. After all, he is a normal person and now he is married and has his own kid. Dan Cao is a less intelligent person, isn't he? As time goes by, we no longer have as much (contact)...

Q: Did he ever invite his classmates over to play?

Cao's mother: No. At that time how could he (understand)... Now he will invite his buddies at the Sunshine Home to come over to play. He will also treat them with snacks.

Q: Did you refute at that time when your son was scolded by others?

Cao's mother: Refute to whom? You spoke up only to be dismissed from school. The same thing happened in the kindergarten.

Q: So they kept him out of school?

Cao's mother: They kept him out of school. At that time, there seemed to be little attention to this aspect. How I wished he could go to an elementary school to learn a few more characters. His brain could not control his hands, but at least he could

\footnotetext{
${ }^{2}$ According to the classification criteria adopted by the second national disability sample survey in 2006, people with intelligent quotient (IQ) of 70 and below are intellectually disabled.
} 
recognize the characters. I kept paying visits to the Education Bureau and schools for people with intellectual disabilities, but in vain.

Two years later, we still wanted to find a way for my son to receive an education, so I went to the Education Bureau of Hongkou District on Wujin Road. My son had previously studied at Limou Elementary School. According to the Education Bureau, Limou Elementary School did not return my son's information to them, so I had to go back to Limou Elementary School to ask the teachers to do so first. Then I went to Limou Elementary School, but was told that they had submitted the information a long time ago. I went to the Education Bureau again, but they said they never received it. They were just trying to pass the buck. I suggested they could call each other to see which side or which step had caused the problem, right? Anyway, I went back and forth between the two organizations countless times. In the end, I was told to contact the school for people with ID by myself. The school was located within the community of Xing Fu Cun, near Dalian Road. I was told to find out where the school was by myself.

So I went to find the school, but the school said that they could not accept Dan Cao without the Education Bureau (proof), because "how could we know whether you are residents in Shanghai or from elsewhere?" I said that I could show them our household register to prove that we were local residents from the Hongkou District of Shanghai. "We cannot accept him. We only enroll according to the name list sent by the Education Bureau." Oh, so much buck passing. I took leave from work and paid visits to these organizations for more than a month. I felt really frustrated... Finally, I decided to give up. So he stayed at home.

Q: Without schooling, how did you teach him reading and writing? Using textbooks?

Cao's mother: No. I was very busy all day long, and at that time my mother was not very well. I had a day off from work every other day, so sometimes I would take him to my mother's house to be a helping hand. In the afternoon when we got back home, I would say, "Dan Cao, do some reading and writing, okay?" He would doodle on the books for a while. Tied up with housework, I had no time to supervise him, so...

We bought him so many comic books in the past, all of which ended up being torn apart by him...

Q: Have you ever given him any guidance on learning?

Cao's mother: Yes. Actually, my son has a very good memory. When he was young, we taught him some English words like apple, tiger, bicycle, soccer, etc. To be frank, my memory is failing as I become old. He still remembers those words clearly.

What he remembers, he remembers. He just could never learn how to write. Even today, he still cannot write his own name. I told him, "You have to know how to write your name." He said, "I cannot hold the pen."

Q: Has there been any training on his intelligence?

Cao's mother: Training? There were no such training schools at that time. We just taught him by ourselves. No special training. 
Q: Later there was not much teaching at home?

Cao's mother: Not much.

\section{Lonely Growth with the TV for Company}

Q: Could you describe a typical day at home?

Cao's mother: A working day would be like this: My work usually started at six in the morning, so I had to leave home at five. I got up very early, sometimes around four o'clock, and then would prepare breakfast for the family. After that I would tell them, "Get up, wash up and then eat." Sometimes I would bring the laundry to my workplace. I worked in the canteen, so once cooking was done, I would do my laundry during the break. There was a washing machine in the canteen. After washing and spin-drying, the clothes would be carried back home and they would only need to be further dried in the sun. This could help save quite some time (giggles).

My work would finish at half past two and sometimes (would be earlier than that). Nobody at my workplace knew Dan Cao's situation, but I had pretty good relationships with my colleagues. Sometimes I would tell them that I had to leave a little early, in which case I would arrive home at two o'clock.

Q: When you left home for work, Dan Cao would not have got up.

Cao's mother: Right. My husband worked on regular shifts that started at eight. Before he left home at seven-thirty, he would see to it that Dan Cao had his breakfast. While we were at work, we would ask an old woman downstairs to take care of Dan Cao.

After Dan Cao dropped out of kindergarten, I first asked an old lady living on the ground floor for help. I said to her, "Auntie, thank you, please help look after my son." Since my husband worked on regular shifts, I would try to work on morning shifts, starting early and finishing early. Every day I would also bring some snacks from my workplace for her. I felt obliged to do so. In order to ask her to look after my son (giggles), I kept buying her gifts. Later she said because we lived in the same building she was too embarrassed to refuse me. I told her, "You could leave him alone. Just let him stay in the back room on the third floor. Go to see how he's doing every hour to make sure that he does not get into trouble or tamper with the electricity or gas. I will not pay one penny less to you. You will be paid the full amount." He was generally very timid, and would not mess around. However, I had to work for $8 \mathrm{~h}$ after all, so I still felt rather uncomfortable that nobody was home with him. After all, he was only 4 years old. She then agreed to look after him for me.

Later, however, the old woman on the ground floor refused to look after him anymore, because an accident occurred...

He grew up. When he was in his teens, he refused to take a nap in the afternoon. The old woman, however, needed to take a nap. She then let him sit beside the gate downstairs, telling him not to walk away. My son was very disciplined. He said yes and remained there. There was a boy a couple of years younger than him, who lived in the front section of the building. He ran over towards Dan Cao, called him a fool, threw stones towards him and then immediately ran away. He repeated this several times. Very sensitive to the boy's words, my son was really exasperated. He picked 
up the stones thrown at him and waited. Unaware of this, the boy came over again and called my son a fool! Out of sheer anger, my son threw a stone at him.

That boy had thrown stones at my son four or five times but missed the target. Maybe hit his hands or feet, but that would not have hurt. My son, however, was prepared. He threw the stone and it hit right in the corner of the boy's eye. His eye became swollen right on the spot.

I was unaware of this because I was at work. Work finished at six and I got home at seven. After seven o'clock, that boy's father came to look for me. He avoided mentioning how his son bullied my son, nor the entire story. He simply said, "Your son threw a stone at my son today. My son's eye was hit and is now very swollen. We don't know yet if he will be blind or not in that eye." I said, "Oh my god, what shall we do?! You take him to see a doctor right now and I will be responsible for all the expenses, including the medicine prescribed. Now it's already half past seven. Since my son has intellectual disability, please do not hold him liable for that. I would like to quickly prepare some food for him to eat. I'm fine without a meal, but I cannot let my son starve. Please take your son to see the doctor first and we will rush to the hospital after my son eats his supper." Shanghai General Hospital is just across the street, you know, fairly close.

After I appeased that parent, I started to cook for my son. I blamed him, "Damn it! You've caused a lot of trouble today!" I could not blame the old woman on the ground floor, although she was supposed to be responsible for supervising him. She even tried to hide the truth. What she said was that "Your son was not behaving himself. He threw stones at others." I told her that I had brought up my son all by myself and the neighbor living opposite to us looked after him before as well. My son was known to be a very obedient boy. I was not trying to defend my son, but if he was not provoked, he wouldn't have behaved like that.

The next day, the two neighbors living opposite to us told me, "You don't need to pay that guy for his son's eye check-up." I said no, because my son was responsible for his swollen eye. The neighbors said, "Don't pay him a penny. We can be your witnesses. It was his son that called your son names again and again. We actually told him not to do it, but he still ran over to your son, threw stones at him and called him a fool. It just happened that when your son threw the stone, it hit him." I said, "Would that help? The old woman on the ground floor would not tell the truth. Are you going to be my witnesses in front of him?" They said, "We will be witnesses for you. We would speak up for you." Then two or three neighbors who witnessed the incident went to that boy's parents and said, "What a shame that you should ask Ms. Wang to pay for your son's eye check-up. Your son threw stones at her son five or six times. We told your son to stop calling names and throwing stones, but he continued to do so. Dan Cao finally threw the stone back because he was too exasperated to stand it any longer. And the stone he threw was the one that your son had thrown at him." After three or four people pointed this out to the guy, he seemed to be embarrassed, and he said that the old woman on the ground floor didn't tell him these things. She simply said that Dan Cao threw the stone. I said, "It does not matter. Let me know how much you paid for seeing the doctor and I'll compensate you for that." However, he was too embarrassed to let me pay the money. I felt really 
bad hearing that someone else's son threw stones at Dan Cao, but I had no way to prevent it.

There was another old woman living on the second floor who was really very nice. She said to me, "There are many kids in my family, so I cannot look after your son, but I can keep an eye on him." Her daughter-in-law was taking sick leave from work during that period of time due to breast cancer. She helped to look after my son a little bit as well. On hot days she would say, "Dan Cao, come to our house and enjoy the air conditioning. Our house is a little cooler; your room at the back is too hot! If you get heat stroke, your mom would be worried sick." He was unwilling to go to their house. I asked, "Why not? Even to cool off for 1 or $2 \mathrm{~h}$ would be great." He said, "No, I do not want to go. Mom, my brain is not good. If I go to their house, they would give me the cold shoulder. I'd rather watch TV at home than go to their house. Leave me some cold water and I'll drink. Sometimes Granny would come upstairs and bring me some refrigerated green bean soup." That's why I have always been very grateful to her. She once said to me, "Wang, whatever nice things you've had in your house, you've given them away to me." "Yes," I replied, "because you've been so nice to my son, even nicer to him than to me, a lot nicer." You know we have logical thinking and are able to understand things, but he, being such a kid, doesn't understand much so he needs care. Oh my, I really feel sad when it comes to him (sobbing).

I bought a TV, but I did not buy a color TV for fear that it would be bad for his eyes. I purposefully asked someone to help me get a black-and-white TV for the back room. He watched TV all day long, but when he felt tired, he would take a break.

Q: He watched TV all the time from 7 or 8 years old till 20 ?

Cao's mother: Right.

Q: He watched whatever programs he liked?

Cao's mother: Generally speaking, I would help him choose the programs, but he would make his own choices as well. He usually would watch Popular Old Songs. He liked to watch singing programs.

Q: Has he ever offered to sing for you?

Cao's mother: He really enjoys singing. He knows many songs and singers, the names of which I have no idea (giggles).

There used to be a TV program Popular Old Songs. He really enjoyed singing. He would say, "I'll sing!" And then he would sing along with the singers in the program. He would say, "Mom, let me sing for you."

Whenever there were singing programs, he would say, "Mom, let me watch this. I'd like to listen." After that we would find singing programs for him to watch every day.

Q: Have you ever thought about developing his singing ability?

Cao's mother: Oh, this has never occurred to us (giggles).

Q: After you finished work, that is, after two or three in the afternoon, basically it would be you who took care of him?

Cao's mother: Always me. After I got home from work, I would help him a little bit with learning. Reading is fine, but when it comes to writing, his brain simply could not control his hands. He could not write. 
His father would finish work at half past four. Since he took management roles in the company, usually there would be meetings for him to attend, so he would be home rather late. I would do the cooking. He wouldn't be home until after six o'clock when dinner was ready. Once he was home, he would help me to take care of the kid as well.

Q: When did he learn to take care of himself?

Cao's mother: Whatever things he was supposed to learn I have taught him, and he is now able to do it all.

He can dress himself, which he was able to do without being taught. After he gets up in the morning, he will fold up his quilt in the back room very well. When he comes home from the Sunshine Home, he will also change his clothes by himself.

Q: Does he help you with your housework?

Cao's mother: Sometimes, when we asked him to do so. When he came back from the Sunshine Home on weekends, I would tell him to help pick the edible parts of vegetables for cooking. He would say, "No problem, leave it to me." He would do things like peel green soy beans, which he can do really well.

Q: When was his father dispatched to work in Xiamen? He was away from home for a dozen years.

Cao's mother: Well, at that time the company was not doing well, so later... when Dan Cao was 4 or 5 years old, he was dispatched elsewhere.

Q: He was dispatched when Dan Cao was 4 or 5 years old, and he came back to work in Shanghai when Dan Cao was almost 20?

Cao's mother: Yes.

Q: A long time.

Cao's mother: Indeed, more than 10 years. After that, they wanted to dispatch him again to work in Baoding. We refused. I told him, "I would rather you be laid off than work there. I really suffered taking care of the family alone. You only visit us several times a year and each time you would stay only about half a month. He always travels by air, every 3 or 4 months, because he could never take his mind off us. After all, I was bringing up the kid alone, right? Let alone working at the same time.

Q: So you were actually always on his mind while he was away.

Cao's mother: Well, he would call us every day, every day, but sometimes we would not be at home. One day, somehow there was no electricity at home except for the kitchen area. What was I supposed to do? I could not get any help. I asked someone to fix the problem, but according to them, our house was too old for them to be able to fix; they had no idea where to reconnect the power. So I called him, but he said he could not help me, either, because "I have just taken leave for a family visit so no way to come back again." What could I do then? I had no choice but to have a very, very long wire connected from the back room to the front through a very long power strip, otherwise I couldn't even use the refrigerator. I told the repairman that I did not require anything else but that the power strip could ensure getting power to the refrigerator. What about the power supply for the rest of the house? For me, the power strip would be enough to support most of the power consumption in the front room. I could manage to do without the others except for a desk lamp. The power 
connection was finally fully restored 3 months later after he came back home again for a family visit.

Q: You can't have no man at home to take charge.

Cao's mother: Indeed. Later he said, "I'll call my father to come over and take a look." I said, "No no no. Your father is rather weird and lukewarm to us. I would rather leave it as it is now. No big deal. Let us just wait until you come back." (giggles)

At six o'clock in the morning, I woke up Dan Cao, telling him to go to sleep in the back room because I didn't feel it was safe to leave the front door open. After all, I wouldn't be home for the whole day, right? Even so, our house was still broken into by that little guy who lived behind us.

Q: Oh, when?

Cao's mother: I went to work and I told Dan Cao to stay in the back of the house. It was around six o'clock on a cold morning, so Dan Cao fell asleep again, having no idea what happened. It happened just at that time (the thief broke into the house). In that year, the five-drawer chest happened to be on this side (pointing her finger to the position of the chest). I did not like to take furniture keys with me, so after I locked the first drawer of the chest, I put the key in the second drawer of the chest. There was a small window in Dan Cao's room, and that little guy climbed into our house through that window. Now my husband has blocked the window with boards (giggles). Those days, I did feel that the money I put in the drawer became less from time to time. He did not steal all the money in one go, because otherwise you would know. For example, if I had 5,000 yuan in the drawer, he would take 1,000 yuan. You would find it difficult to tell this to others, because people would say, "You jerk! How come the thief didn't steal all the money, only 1,000 yuan, with the lion's share still there?" You got me? I couldn't bring myself to complain about it, so I just remained a silent victim instead. I kept losing money, sometimes a few hundred and sometimes a thousand. He came in through the window and went out through the door after properly shutting the window and the door, so you had no idea that someone had entered your house.

After losing money for a period of time, about a few months, you know how we discovered it? It was time for the Spring Festival, and we were to celebrate my husband's 50th birthday before the Spring Festival. My mother said she had not bought a gift for my husband, but because my husband treated her really well, she would like to have the gold ring kept in the family melted to make a bigger one for my husband. I said, "No, let him buy it himself. He is able to make money in Xiamen." My mom said, "If you buy it, it's just something you buy. As for us parents, this is a small token of our appreciation." I then agreed. That day, my mother and I took the newly made gold ring back home, and I still put it in the drawer. In the evening, I called my husband to tell him that my mother prepared a big gold ring for his 50th birthday and it was already waiting for him in the drawer of the chest in our house. The next day, after I returned from work, I opened the drawer only to find it was gone. He came to steal again.

Q: So this was finally discovered?

Cao's mother: The theft this time was the most obvious. 
So I cried and cried at home. Later, the neighbor on the second floor asked me why I had been in low spirits. "It seems that you have been in a bad mood over the past 1 or 2 months." You know the neighbor on the second floor had always been on very good terms with me. I told her, "I have a lot of things on my mind, but I dare not talk about them with you guys. Please don't get me wrong when I tell you what happened to me. In the past month or two, money has been disappearing from my house, though not in large amounts. For example, if I put 5,000 yuan in the drawer, the next day after I come back from work, I will find there's only 4,000 yuan left. A few days later, several hundred will be gone, and after a few more days, several hundred more will be gone. Can you believe that? If this was done by a thief, how come the thief would only take away 1,000 yuan? However, last night, I put a gold ring in the drawer that my mother bought for my husband, and today after I came back from work, it was gone." She said that I had to report it to the police. I said fortunately the receipt of the gold ring was still there. I was so stupid that I didn't even know how to report it to the police, because I had never had such an experience before. Finally, I called my younger sister, who accompanied me to the police station.

There was a police station administering public security work on Gaoyang Road. The police car sent me there to record my report in writing and I was reprimanded for failing to manage my personal belongings properly... They asked me who I thought was the suspect and I said I suspected it was that young man who lived behind us, Zhao.

Originally the entire third floor belonged to us, and it was acquired by my husband's grandfather with 52 gold bars from the Japanese. During the chaotic Cultural Revolution, one room was confiscated, but that was a very small one, only a little more than 7 square meters. This young man who lived behind us was from the countryside. I have no prejudice against people from the countryside, but he would even steal my son's money. My son had a savings box, and he liked to put it in his room at the back so that he could count the money in it whenever he wanted. I thought it was fine, because the highest value of the coins was 1 yuan, and the rest are 50 cents, 5 cents, 2 cents, or even 1 cent. Anyway, that was a large box of coins. How did we discover the money inside it was gone? Well, one day after I got the breakfast and other things ready for him in the morning and was about to go to work, I noticed that I had no 1-yuan coins in my purse to pay the bus fare. "Dan Cao, please give me 2 yuan from your savings box so that I can take the bus." After we poured out all the coins from his savings box, those 50-cent and 1-yuan coins were all gone. We could not even find any 10-cent ones. There were only 5-cent, 2-cent and 1-cent coins left. I questioned Dan Cao about where the money was. He said he didn't know. According to him, Zhao would count the money for him. "Each time after he counted the money, when I shook the box, I would feel that there was less money, but I have no idea how much less." That guy took all the 1-yuan and 50-cent coins away, as well as the 10-cent ones. At that time, he was studying at a vocational school. He seemed to be older than Dan Cao.

It was already seven o'clock. I couldn't talk with him about this matter any longer because otherwise I would have been late for work. After I returned from work that day, however, Dan Cao was in tears. He told me, "Zhao ate all my food today!" The 
lunch I prepared for him that day was Yeung Chow Fried Rice, a combination of rice with sausage, egg, and green beans. I asked, "How did he end up eating it?" Zhao just put some white rice there. Dan Cao had his own tactics, though. He said, "I'm not going to eat that rice. I'm going to leave it for my mom to see! You ate my food." Oh, I was really mad at this. I reprimanded Zhao, "You bastard! How could you eat Dan Cao's meal? He starved for the whole day! If you like it so much, you could just let me know and I would cook more for you. You cannot just eat his lunch! He starved for the whole day!"

At the police station, I reported these two incidents. I said that I suspected he was the thief, because we had lived in the building for decades and no thefts had ever occurred. In the past, on hot days, we all slept with our doors open at night and no such thing had ever happened. That's why I cast my doubt on him. His family were the only newcomers to our building. I didn't discriminate against new neighbors, but ever since his family moved into our building, a lot of things have happened.

The young guy happened to have winter examinations to take at that time. The police said they would have to wait for a few days to start their investigation. It was probably not until the last day of his exams that he was directly taken away by the police from the school after he finished all his exams. This was the first time (he had got arrested), so he confessed everything. All the thefts were committed by him. Well, the police officers said to me later, however, "You are such a careless woman. He has stolen far more things from your house than you are aware of." He had also stolen other things such as my husband's big-brand shirts (giggles).

Q: You didn't find out, did you?

Cao's mother: No (giggles). According to the policeman, he also stole a pair of Parker pens from us - which were given to my husband by someone as a gift-and sold them. The receipt for that gold ring was still with me. That ring cost more than 3,000 yuan over 10 years ago, and he sold it for 700 .

Q: What's a typical day in your family like now?

Cao's mother: Sometimes my husband and I will do some exercises on the balcony after getting up in the morning. After seven o'clock, we'll wake up Dan Cao. Dan Cao leads quite a regular life. Every morning, he'll go to the washroom first, and then wash up. After he finishes his breakfast, he goes to the Sunshine Home.

Q: Who takes him there, you or your husband?

Cao's mother: Me, in most cases. But after I got burnt, my foot was burned by boiling water, although he still wanted me to take him there, I told him that my foot wouldn't allow me to do it, so his father takes him there these days.

Q: Are there any disagreements between you parents when it comes to taking care of him, receiving treatment, and education?

Cao's mother: Generally no. My husband always goes along with whatever I decide.

Q: Has Dan Cao ever expressed his appreciation for what you have done for him and his love to you?

Cao's mother: Yes, he would say such things.

Especially to me, but not very often to his father. After all, his father was not home for more than 10 years. He just visited us several times every year and each 
visit would last only a few dozen days. To me, he would (say), "Mom, you've done so much."

Q: Do you feel especially happy upon hearing this?

Cao's mother: Very, very happy. My son has grown up, after all (giggles).

\section{Beaming with Joy After Returning to School}

Cao's mother: In the 1990s, due to poor business, the company I worked for was to be dissolved. My husband had been dispatched by the company to work as a manager in Xiamen. Then the boss suggested, "How about going to Xiamen together with your husband?" I said, "To leave my hometown as well? I've never lived there. Let me go to see the place first. If I can adapt myself to the life there, I'll stay; otherwise I won't. I have a requirement as well. I must bring my son along; otherwise it's not going to happen." The boss agreed, "Okay, you can go to see the place first." So I went there and found that I felt comfortable with the air and food there. I asked Dan Cao if he would like to go to where his father worked and he agreed. So we stayed there for one and a half years.

In Xiamen, we met a director of the organization department of the Party committee at the district level. Knowing that our son did not have good intelligence, he asked us if we would like to take him to a local school. People in Xiamen were really different from people in Shanghai. They were very ... really very, very friendly towards my son. I told the director, "But my son has never gone to school, he was even abused by teachers and called a fool at school in Shanghai. My son feels inferior, so we are afraid to send him to school." He assured me that the local school was very good, so Dan Cao studied at that school for about 7 or 8 months.

Q: Which school?

Cao's mother: Pei Zhi School, which was a school for people with ID in Xiamen. He studied there for 7 or 8 months. I sent him there in the morning and picked him up in the afternoon. It was really a good school and the teachers were very good. My son got along with them quite well.

Q: I see. Have you been to their school?

Cao's mother: Yes, I went to their school every day. I took him there and picked him up every day.

Q: What do they teach?

Cao's mother: Well, Chinese, arithmetic, and also painting and singing. There were many foreigners there, and their school was frequented by the wives of Singaporean and American expatriates.

Q: Oh, did Dan Cao like the school?

Cao's mother: Yes, he did. The school in Xiamen had one issue, though. There were also students with a propensity for violence.

After Dan Cao studied there for 7 or 8 months, I said that I did not want to send him to the school anymore. Dan Cao was already over 20 years old by that time, which was 10 years ago. Later, my niece got married, and my sister called to invite us to her wedding in Shanghai. So I brought Dan Cao back to Shanghai, but my husband stayed in Xiamen. I told my husband, "I don't want to stay out of Shanghai for a long time, so I would rather remain in Shanghai with Dan Cao. You have been 
working so hard away from home for more than 10 years, so look for opportunities to (come back) as well." He came back to Shanghai a year later.

Afterwards, the company dispatched my husband to work in Baoding, but he did not adapt himself to the life there very well. According to him, Xiamen was fine, because he originally came from Ningbo, which had one thing in common with Xiamen: a lot of seafood. He was not, however, used to the lifestyle of the north. As a result, he stayed in Baoding for half a year and decided to quit. I encouraged him to come back and retire, so he quit his job.

Q: Dan Cao went to school in Xiamen for 7 or 8 months. Why was it discontinued?

Cao's mother: Our household was not registered there... We actually lived there for one and a half years. My brother then called me, "If this is the case there (going to school), let me take you (through introduction) to Shanghai Children's Home, where they also teach reading and writing. So, we went to Shanghai Children's Home after we returned to Shanghai.

Shanghai Children's Home was in the community of Xing Fu Cun, near Dalian Road. I asked Dan Cao if he wanted to go there, and he said yes. So I sent him there. In fact, he was already over 20 years old at that time, beyond the age limit for enrollment. My brother actually helped to let him in "by the back door." After my son was enrolled into the school, the Principal once said to me, "Your son looks so neat and handsome, how come he would end up in here..."

He was at Shanghai Children's Home for about 5 years. I was on very good terms with Teacher Tang and Teacher Ye at that school (giggles). We are still occasionally in touch with each other even today. They taught the kids singing, painting, and writing. I observed their classes. There were no teaching objectives for them to fulfill. They just taught the kids to do what they could do."

Twenty years ago, I was already doing volunteer work, and was the Chairman of CAPIDR. Later, after the establishment of the Sunshine Home, community leaders came to talk to me, "Since you are the Chairman of CAPIDR, we would like to have your support, and you should send Dan Cao to the Sunshine Home."

Q: What is CAPIDR?

Cao's mother: China Association of Persons with Intellectual Disability and their Relatives.

I had been doing work for this Association before we went to Xiamen. At that time, no one was involved in such work in the community. A leader in community work contacted me. I had a full-time job back then and Dan Cao was only 16 or 17 years old. He did not go to school and stayed at home instead. The community leader told me, "You can obtain a Certificate of Disability for Dan Cao, but prior to that he has to take an IQ test." I said okay, and took him to have an IQ test. After that, we obtained the Certificate of Disability.

Shortly after we obtained the Certificate of Disability, the leader contacted me again, asking me if I would be interested in working for the disabled. I said, "I know nothing about it because this field is totally new to me. Dan Cao has just obtained the Certificate of Disability, and I don't even know what it is." He said, "No worries. We can work together. Unlike others, you seem to be very caring about the disabled. You should go and look after them more." 
Afterwards, I was called to meetings at municipal and district levels from time to time. At first, I did not understand much, but gradually I acquainted myself with the work through experience.

Q: Why did you agree to go to the Sunshine Home?

Cao's mother: I agreed to go after some consideration... They had noticed that I had been taking very good care of Dan Cao. That leader said, "Many parents would reject their kids if they had such problems. Now at the Sunshine Home, there are also many parents who neglect their kids. Sometimes we would talk with these parents, telling them that they cannot treat their kids this way. As soon as a kid is born, it's a form of life, so we have to treat the kid well."

We had put (Dan Cao) in the Children's Home. There seemed to be foreign friends visiting them every day. Anyway, there were frequent interactions between them and foreign friends, twice or three times per week. He felt very happy. I told him, "The community has told me to support the work of the Sunshine Home. There are not many students in the Sunshine Home, so they recommend you go there." He said, "I don't want to go. I feel very happy at the Children's Home."

At that time, the Sunshine Home was newly established, and there were no meals provided. In each community there was a Sunshine Home and we belonged to the Jiaxing Subdistrict. However, our house was the farthest away from the Sunshine Home of Jiaxing Subdistrict. The street opposite to us belonged to Chuanbei Subdistrict. I said to our subdistrict leader, "It's not that I'm unwilling to send Dan Cao to the Sunshine Home in our community. It just that they have to provide meals, so that I can send him there in the morning and pick him up in the afternoon. At the moment, I have to pick him up at noon for lunch, and then take him back after lunch. I have to go to and fro four or five times a day, and each trip takes more than half an hour. I cannot do that. He is now very used to the life in the Children's Home." The community leader insisted, "You are the chairman of CAPIDR. There are a few students at the Sunshine Home in our community, so there's the possibility that it would be merged with another Sunshine Home in another community. You'd better transfer Dan Cao into it."

The Sunshine Home of our community was originally situated on Old Hongzhen Road, and it was later relocated to Tianbao Road. The community leader then told me, "We offer meals now." I said, "I support your work, and we will send Dan Cao over. There are winter and summer vacations at the Children's Home, so after the summer vacation starts, that is, from July 1, I'll send Dan Cao to the Sunshine Home every day until August 30 to have a try. Let's see whether he feels more comfortable at your place or at the Children's Home. If he gets used to life at the Sunshine Home, I'll let him stay and quit from the Children's Home. Actually, the Children's Home charges 400 to 500 yuan per month while your place is free of charge. However, we have to see which place he feels more comfortable and wants to stay at. I would never neglect my kid's feeling just for the sake of saving some money."

During the summer break, I told Dan Cao, "Today I will take you to the Sunshine Home to play with other kids. It's up to you to decide whether you would like to stay for half of the day or the whole day. At home, you always watch TV all day long. How boring is that. I have many things to do, such as cooking and doing laundry. I 
don't have time to talk to you. At the Sunshine Home, however, there are many other kids. I will wait for you there, and I will be with you." He said, "I don't know them, and they will look down on me." He always says that people will look down on him. I told him that would not happen because the kids there were in the same condition as him. He agreed, "Okay, let's go then."

After he went there, the first day was fine, but the next day he felt awful. That was because the Sunshine Home was at the same venue as the Sunshine Psychiatric Garden, which was for people with mental disorders. He said, "Mom, I don't want to go..." I said, "Why? You don't need to talk with the kids in the Sunshine Psychiatric Garden; you can just talk to the kids in the Sunshine Home."

However, there were a few kids from the Sunshine Psychiatric Garden who kept looking for him to talk and to... "If they talk to you, do not reject them. If you turn them down, sometimes their mental disorder may recur in spring."

Even today, as the Chairman I am still lobbying to the community together with the Vice Chairman of our Association on this matter. I said, "You have to find ways to separate the kids with mental disorders from the kids in the Sunshine Home. It will be terrible if accidents occur." I did not propose this because I was the Chairman. In fact, I was also worried about the other kids, because you don't know when the disorder will recur-they appear normal when their mental disorder is suppressed. Yet if it recurs, it's hard to tell the consequences. The kids in the Sunshine Home were different. They won't attack others, physically or verbally.

Once, a kid's mental disorder recurred, and he punched Dan Cao twice in the chest. Dan Cao told me, "I was just sitting there watching TV. He came up to me and punched me twice." At first, Dan Cao didn't even bother to tell me, but when I was picking him up, his teacher had to tell me, just in case something went wrong later. The teacher told me to bring Dan Cao to the hospital if he felt his chest congested. I asked why, and the teacher told me that Cheng punched Dan Cao. I asked, "Why did he punch Dan Cao?" The teacher said, "Today Cheng's disorder reappeared, and we couldn't control him." In the evening, I asked Dan Cao if anything went wrong. He said he was fine, so I just let go of it (giggles).

Q: So for this reason, he didn't want to go to the Sunshine Home at the beginning, but later on he got used to it?

Cao's mother: Exactly. He got used to it later on.

Well, (I told him) not to be in contact with them too often, but he was sociable and very friendly. According to him, he felt bad rejecting people when they approached him for a chat.

Later on, after 2 months of staying there, he got used to it and got along well with the kids there. Therefore, I didn't let him return to the Children's Home, instead he stayed at the Sunshine Home.

Q: Does he go to the Sunshine Home by himself every day?

Cao's mother: No, I take him there. From our house, we need to pass Hailun Road and Wuhua Road, and then walk farther down a little bit (to arrive there). There are many cars on Hailun Road. What's worse, now there's the tunnel, and there is no traffic light, so I don't trust him going there alone. He always tells me that he is old enough, so I don't need to walk him anymore. However, I tell him that I (don't feel 
comfortable). Once a kid from the Sunshine Home was trying to cross the street at Hailun Road, but he was hit by a car, and the car just drove away. How can I trust him going there alone? I feel concerned. That's why I take him there and pick him up every day.

Q: He has never been anywhere by himself so far?

Cao's mother: No.

Q: You always fetch him here and there?

Cao's mother: Yes.

Q: What are the daily activities for him at the Sunshine Home?

Cao's mother: On Monday, there's a singing class by the President of Little Apple Art Troupe; on Tuesday, there's an English class by a foreign teacher; on Wednesday, there's a painting class by an artist from the Art Association; on Thursday, there are lessons by me and Teacher Zeng; and on Friday, Teacher Zhou has now found a coach who will teach them how to play wiser ball (See Fig. 1).

Q: Quite some activities.

Cao's mother: We do have lots of activities at the Sunshine Home. I was there the whole morning today (giggles) to take them to watch movies. The Sunshine Home also organized for them to sing at Prince and Princess KTV in the afternoon.

$\mathrm{Q}$ : What do they do in addition to classes?

Cao's mother: Sometimes, the teachers at the Sunshine Home will teach them how to string beads, or do some simple handcraft work. However, Dan Cao is very clumsy. You know what has made me feel touched most? Once their teacher was teaching them how to string beads, and the smarter kids already knew how to make

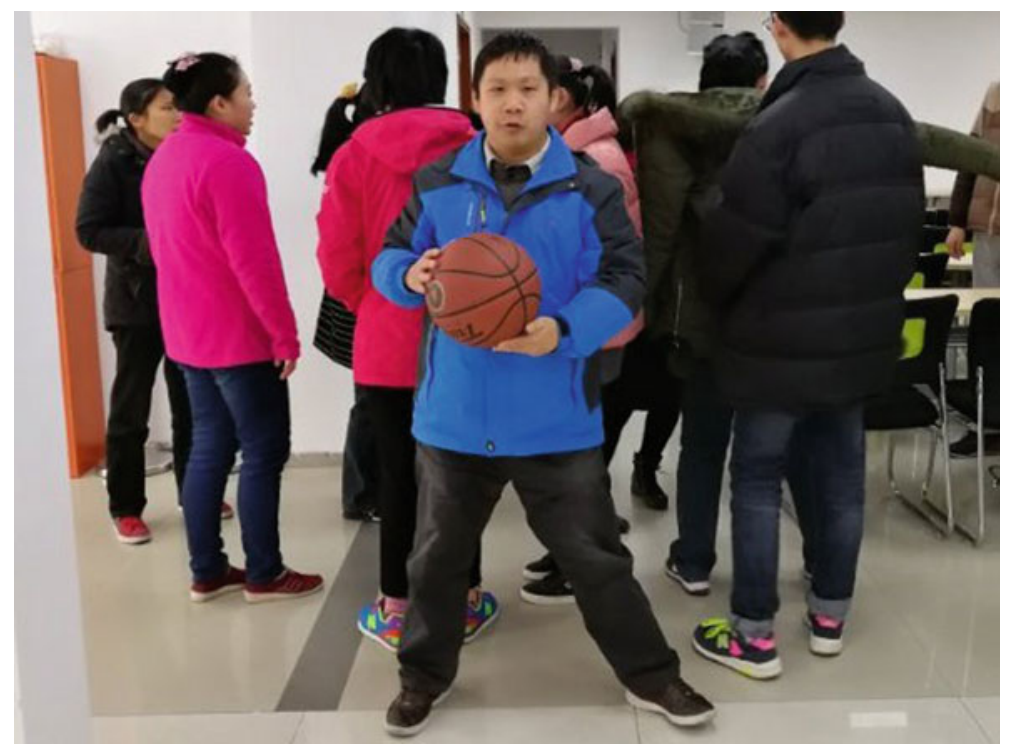

Fig. 1 Dan Cao doing exercise at the Sunshine Home 
artwork such as shoes. I said to the teacher, "Dan Cao (doesn't even know) how to string beads. He can never get the beads on the string!" That teacher was very patient. He said, "Today I am going to teach your son, and we are going to have a competition later." "How are you going to teach him?" I asked. He said he would teach my son to string one bead at a time. I doubted that Dan Cao could get the string through even one bead. You know why, I know my son too well. His brain can't control his hand. So if you ask him to hold the string in one hand and the bead in another, and then get the string through such small holes, there is no way he would be able to do that. The teacher told me, however, just to sit aside and be quiet. He also mentioned that they had taught Dan Cao several times, and that Can Dan could already string a lot more beads. I was very curious to see. So I sat at another table, observing how the teacher taught him.

They each got a little basket. The teacher said, "Dan Cao, you are competing now. Try to string a lot of beads so you can come in first place..." Then, Dan Cao started to string the beads and it was this long (with hand gesture) - the string went through the tiny beads, one after another. I was so touched that I was about to cry (giggles). He never knew how to do that before.

I praised him! I told him, "Dan Cao, you are amazing! Now you can even string beads."

He said, "I am really happy today, Mom. I got an award. I got a pack of liquid detergent." We have stuck all his award certificates on the fridge.

Q: Does he tell you about what he does at the Sunshine Home after school?

Cao's mother: Yes. Since we want to train his memory, I have told him to report to us what he has for lunch every day. Every day after he gets home, he would tell us what he ate for lunch, such as dumplings or noodles... I require him to even tell us the filling of the dumplings (giggles). Well, he is able to tell us that. I told him, "We ask this not merely for the sake of knowing. Make sure that you don't give us the wrong information. I'll call your teacher to check. You can't fool us."

Q: What will you do on days when you don't go to the Sunshine Home? Do you go out to play?

Cao's mother: Yes, we take him out to play sometimes. In fact, these kids are lonely; so are their parents. We like to organize parent-kid field trips. This time we organized with Teacher Zhou and parents from the Sunshine Home to go on a 3-day trip from the 15th to the 17th. There is a kid named Liu in the Sunshine Home, and his parents are both middle school teachers-one compiles math textbooks and the other teaches Chinese. I once asked the boy whether he enjoyed his recent trip with his parents. "It was boring..." he said, "I was on my phone for 3 days." When I asked why, he said it was all old people who he had nothing to talk about with (giggles). So, Teacher Zhou proposed that we should organize our own trip with the kids, so that the kids can play among themselves. Later on, I said to Liu's dad, "When you brought Liu on a trip, it was just old people, but this time we are going to organize our own trip. Are you coming?" He said of course he is (giggles).

In fact, the kids communicate a lot among themselves. They may even ask, "What is your father doing today?" "What do you eat at home?" "How's your mom doing these days?" They will ask after each other and they care about each other. 
Q: Does Dan Cao take the initiative to communicate with others?

Cao's mother: He usually doesn't talk to strangers. However, after he gets to know you, he would become extremely friendly.

He usually doesn't talk much. Once there was a kid with autism, but every Thursday when we gave them lessons, we would ask him to answer questions. Sometimes he didn't want to, and I told him that he couldn't be like that, because everyone had to answer questions. You know I wanted him to talk a bit more. Anyway, he took Dan Cao as his good friend. They could sit wherever they liked during lunch, but he always sat with Dan Cao. "Mom, don't underestimate Han. He is really good at table tennis," observed Dan Cao. "He may not talk with many others, but he is really on good terms with me. He calls me brother.” Brother Dan Cao (giggles).

Q: That sounds good. Does he go with you for grocery shopping?

Cao's mother: He does.

Q: Then how about taking a walk?

Cao's mother: Yes. Sometimes I would offer to take him to the supermarket. "I'll go if you take me." He had unpleasant memories in his childhood, you know. There was a small store down in the alley where we lived. Sometimes I would tell him to buy a bag of salt or a bottle of wine for cooking and he ran such errands quite well. Every time he would ask me if there would be any change. We know the owner of that little store, so I would say, "Just give him the money, and if he gives you change, bring it back home." He did that kind of shopping at least a dozen times. At that time, he was very young, maybe about 4 or 5 years old. One day, I ran out of vinegar, so I said to him, "Dan Cao, take the money and go buy a bottle of vinegar for me. Today just a small bottle will do." So he went, but his money was robbed, just in the alley. I don't know where it happened. He just ran back crying, and told me that someone pulled the money out of his hand. I asked him if he knew the guy, and he said no. Anyway, he was traumatized. He's refused to do shopping for me since then. He would say, "No, I'll be robbed."

After the robbery, he refused to use money and he did not want money. Sometimes we would give him money, but he would refuse to take it. He said, "If I want something, I will let you know."

Q: Have you ever tried to help him get rid of this bad memory?

Cao's mother: Yes, but he just doesn't want to do shopping. If he wants something, he will say, "Mom, let's go to the supermarket to buy this or that." I would say, "Next time, you go to buy it yourself." Then he would say, "No, I won't go by myself. I'd rather not have it."

Q: Has he ever tried to work?

Cao's mother: No, he has never worked. He is not able to (giggles). He definitely can't work.

In fact, the Children's Home also ran a factory. Someone offered my son a job there, but I rejected their offer. Why? Because I know my son is bad at doing things with his hands. Other people don't know, because he looks perfectly fine by appearance. However, I am aware that he doesn't have the ability to do that. I told them, "I have visited the school-run factory, and every job is hand related, such as screwing nails... 
My son can't do such things. You guys don't know, he can't even write his name. His brain really can't control his hands."

Q: Do you think there are any aspects that the Sunshine Home could improve on?

Cao's mother: One thing that could be improved is that it would be better if it could be separated from those with mental (disorders). I always feel concerned: what if someone gets hurt?

Another thing is that hopefully, senior-care solutions could be offered to people with ID and senior nursing homes could be built for them. To be straightforward with you, people with mental disorders can be normal when they are not having their episodes. People with ID, however, are always muddle-headed. They are always at a disadvantage even if they are with people with any other type of disabilities.

I thought about having my sister's daughter take care of him, which should be a good idea. However, it's become impossible now, because she got married and is now living in Australia. She said she would try to take Dan Cao to Australia in the future. However, Dan Cao's nationality is Chinese and all of his connections are in Shanghai, so it is not possible. We are really worried about his life when he gets old.

Q: Have you thought about what to do in the future?

Cao's mother: I have discussed this with my husband. My opinion is that we have to plan well now. In the future, we are not going to rely on anyone. And if either of us two passes away first, the other one, even if still in good health, shall go to the senior nursing home with Dan Cao, and give all of our properties to the government. Why? This would allow Dan Cao a transition period to adapt himself. The two of us know him very well, but when we both pass away, he would be at a loss by himself. $\mathrm{He}$ is also very shy in unknown environments.

Q: Have you ever thought about him getting married?

Cao's mother: No, never. He has never thought of this, either. He is not like those kids who may have the urge when they reach a certain age (giggles). He's not like that.

Q: Do you have any other expectations on society? Do you have any other plans?

Cao's mother: Nothing in particular, but I do hope to set up a senior nursing home for them.

Q: Are you enjoying any national welfare policies?

Cao's mother: Every month he is entitled to 1,000 yuan as a subsidy for the severely disabled and unemployed, which is used for his living expenses. When we first obtained the Certificate of Disability, the subsidy was only 100 yuan per month. I remember there has also been a monthly subsidy of 280 yuan for 10 years. The amount has been gradually increased in recent years. A flush toilet has been installed for us. No extra allowances for us for holidays or festivals. Oh, there was an extra allowance of 500 yuan for the Spring Festival last year.

Dan Cao has had high blood pressure, maybe inherited from me, for many years. We check his blood pressure on a regular basis and he takes medicine every day. Now he's getting better. Starting from this year, his medical expenses can be reimbursed in full. Up till last year, it seemed the maximum coverage per year was only 800 yuan. 
The Sunshine Home is free of charge. Lunch was offered for free in the past. Later on, though, there seemed to be complaints from other communities, so now we pay a little amount, but it is only 60 yuan per month.

\section{Special Olympics Was Super Fun}

Cao's mother: I attend the district-level council meetings twice a month. There is a director Teacher Zhou who proposed that we should make more effort to develop the intelligence of these kids. I suggested that we could organize a waist drum team. She asked how we could make it (successful) because even normal people don't know how to play the waist drum. She asked me (how to teach them). I said, "Let's do it one step at a time." So far, the drum team has enjoyed a history of more than 10 years. We really taught them by holding their hands to play the drums, bit by bit, and gradually they mastered the skill. So, Teacher Zhou said to me, "Wang, you are really impressive." (giggles).

I have always taken Dan Cao to participate in the waist drum team of Hongkou District. I also play the big drum for the team, because we as teachers have to lead the kids to play the drums. We first learned to play the drums by watching others play. Then we would try them out ourselves and ask others questions that we had. Finally, we were able to teach the kids by ourselves. At that time, the main purpose was to develop the children's intelligence by slowly improving their hand-brain coordination. However, even to this day, Dan Cao's coordination is still very poor. He is not good at this. Some kids can already play very well and they can even do some tricks, just like normal people. We have taught them these skills and tricks.

Q: Was this before or after Special Olympics?

Cao's mother: It was established about 2 years before Special Olympics. Later in 2007, we played waist drums at the opening ceremony of Special Olympics. During the first 2 years, we didn't expect that we could finally make it to the International Special Olympics to be held in Shanghai. We thought it was impossible for us. We just tried out best to provide them good training - to play in an orderly manner and be able to show off their tricks. Half a year prior to Special Olympics, we began to apply (to participate in the opening ceremony). We have a teacher who plays the cymbals while I am the big drum teacher. I would first strike the drum three times, and that teacher would then start to play the cymbals, "bang bang." I told the students, "You all have to play neatly so that we can apply (to participate in Special Olympics). If not, how are we supposed to qualify? There is a qualification test, as well."

Q: How do you train the waist drum team?

Cao's mother: The training was quite demanding. (In order to make it to Special Olympics), extra training was required. Sometimes we started the training early in the morning. The drum team was made up of kids selected from eight different communities of Hongkou District. On Saturday and Sunday every week, we would go to the District Committee (for training). Saturday and Sunday would be dedicated to waist drum training. On weekdays, there was also bowling training. We were very busy during that period.

Since there was no school on Saturdays and Sundays, we used the playground of Miyun School and we had training there for 5 or 6 years. During those years, the 
neighbors made many complaints, because the noise was extremely loud when so many kids were playing at the same time. If they played neatly, it was somewhat musical. However, when they did something wrong and you were in the middle of teaching them, that type of noise was really annoying to the neighbors. Now we mainly do the training in a room at the District Committee with the doors and windows shut, lest people complain and regard us as annoying.

The TV station would always come and shoot to track our progress. Later on, when we were at the opening ceremony in the Shanghai Stadium, Kefan Cao, the host of the ceremony, said to me jokingly, "Teacher Wang, my ears were almost deafened by your drums (giggles)." I said to him, "I actually didn't want to have you stand side by side with me-we are both so fat (giggles)."

Q: Did you train Dan Cao by holding his hands to teach him to play?

Cao's mother: Of course. I could never teach him enough (giggles). Sometimes, he would get annoyed when we held his hands, so he would smash his sticks on the ground (giggles)! He would say, "Oh I'm bored to death! I don't want to participate anymore and my hands are sore." I would respond by saying, "It's okay if you don't want to participate, but don't get jealous when other people are there- tons of people want to participate." He would say, "Alright, let's continue."

We taught every kid bit by bit, with no exceptions. It was a time-consuming process. After it was confirmed that we would appear at Special Olympics, we not only trained on Saturdays and Sundays, but also every Tuesday as well. Sometimes we trained for a full day on Saturday and Sunday. It usually started at eight in the morning, with some water and washroom breaks in between. Sometimes, it would last until two or three in the afternoon. It was indeed tough.

For each extra day of training, we had to tell the teachers of each Sunshine Home in advance so they would prepare enough food for the students to come back for lunch. We gave them a break in the afternoon... You have to train these kids repeatedly, or they would forget everything the next day.

Q: When Dan Cao was with the rest of the kids from the district, did he make new friends?

Cao's mother: Absolutely.

The kids were very happy when they were together. They would say hello to each other and would have lots of things to talk about. In fact, they sometimes communicate less with us but talk a lot more among themselves.

He would tell his peers "you played this wrong; it is supposed to be like this (giggles)." He sometimes would even say, "If you keep playing it wrong, my mom will tell you off again."

Q: Has he ever complained that it was too tough for him to continue?

Cao's mother: Yes. He complained it was too boring and tough. I said, "This is like nothing and you are calling it tough! (giggles)"

At the same time, he found it kind of fun as well. You know why? He got other kids playing with him. To be straightforward with you, these kids are lonely at home, right? Sometimes, when we gave them a break for half an hour, they seemed very happy and very relaxed - it was so much fun for them to play and talk with each other. 
Q: Had you guys been to the venue prior to the opening ceremony of Special Olympics?

Cao's mother: We first went to train at the venue, and then we also rehearsed there about four or five times. The chartered bus of the DPF at the district level sent us there a few times, which we really appreciated. Sometimes after training elsewhere, we had to go to the venue to rehearse our positions. If that was the case, we would not be at home until 11 p.m., which was a very long day for the kids.

If the performance during rehearsal was not up to their standard, they would still reject you. Therefore, we would always remind the students, telling them that "you've been playing hard and you're very tired, but us teachers are actually more tired than you guys. We have to buy costumes and may need to add some patterns onto the costumes as well." At home, I borrowed two sewing machines and several teachers would come over and make changes to the costumes together.

$\mathrm{Q}$ : Did the kids say that they were nervous on the day of the actual performance?

Cao's mother: The kids did say they were nervous, but that was only for a short while (giggles). They were more excited than nervous, actually. Although they said they were nervous, after talking with each other, they would become excited again at the thought that they would perform on stage soon. Dan Cao said to me, "Mom, we cannot mess up today (giggles)." And he also said, "I know it. I will play a bit quieter, so I definitely won't mess it up (giggles)." He is pretty wise.

We were the first performance at the opening ceremony because waist drums are loud enough to enliven the atmosphere. When we finished our performance, we all went out and had dinner together.

On the day of the last official performance, my mom was already in a critical condition (sobbing). At that time, my family was very supportive of our performance at Special Olympics. My mother was critically ill and she was in ICU at the hospital for several days. My sister didn't even tell me about it. On the last day, my sister started calling me, but she couldn't reach me. She called my husband only to be told that I wasn't home... I got home at midnight that day. As soon as I got home, my husband told me, "Call your sister right now. She called you several times during the day, but she didn't tell me the reason. I did tell her that you took Dan Cao to perform." When I called my sister, she cried, "Mom has been seriously ill for several days. Please come over."

I went straight there that night, but before that I helped Dan Cao shower and then put him to bed. My husband offered to go with me, but I said no, "Dan Cao is home. If you come with me who will take care of him?" I called a taxi to get there. When I arrived, my mother was already unconscious, unaware of anything anymore.

My sister said, "I know you had to take Dan Cao to rehearsal and training for Special Olympics recently, so we didn't call you. Mom has been sick for a long time anyway. I know today is your last day, but I didn't know what time you'd be back, so I have been calling you." Sighs...

After the opening ceremony, my mother remained unconscious for a long time, and finally she turned into a vegetative state. When Special Olympics ended, the District DPF invited us teachers on a free trip to Nanjing in recognition of our efforts. I decided not to go because of my mother. My mother had given me most of her care 
and help because of my son. She had never taken care of the third generation, she just helped me to look after my son. She would help me when I was at work. I had an amazing relationship with my mother, so it was impossible for me to leave her behind.

The waist drum team was like a non-government organization. We didn't make money or get anything else from it. We were all just volunteers and we tried to help each other. I was in the waist drum team for 10 years. Many kids were taught by us teachers step by step. Usually, we had to pay for the chartered bus of the District DPF. Dan Cao and I each had to spend 200 yuan on transportation. Finally, I decided to quit the drum team.

Q: Does Dan Cao still know how to (play the waist drum)?

Cao's mother: Yes, but he forgets things really easily. He will forget how to play the drum if he doesn't practice often.

Q: Did he participate in any games at Special Olympics?

Cao's mother: Yes, he participated in throwing balls, which he chose himself. Since I was the Chairman of CAPIDR of our community, I knew all the stories behind Special Olympics.

Q: How did teachers train him? Did he receive a lot of training at that time?

Cao's mother: I sent him to the bowling club for training. Since I was the Chairman of CAPIDR, I would take the students there with other teachers. I did not simply follow-up on Dan Cao, I took care of other kids as well. We have the responsibility of taking care of them all.

His teacher made him the team leader to get the other kids in line (giggles). I also took several kids with me, asking them to walk in line together.

Q: Would he look for you when he couldn't see you?

Cao's mother: Yes, he would. However, I told him, "You can't do that. I can't always be with you. You should stay here with your friends, I need to take care of the other kids, too." He said okay.

Q: How was time split between training and schooling at the Sunshine Home?

Cao's mother: We worked with teachers from the Sunshine Home to choose a few good kids for training at the bowling club. They would receive training for $2 \mathrm{~h}$ each day and at noon they would return to the Sunshine Home by bus for lunch. We had to pay the bowling club, so we asked the District Committee for help. I told them, "If you want us to qualify, please give us support. Otherwise how can we make it?"

The training lasted for about a month. There were two games a day, about $2 \mathrm{~h}$ in total. It was not cheap for a 2-hour training session at the bowling club. We advised teachers of the Sunshine Home to prepare some empty water bottles filled with sand for the kids to practice in the afternoon. The teachers followed our advice.

Q: Did the teachers take them outside of Shanghai for competitions? Or was it just in Shanghai?

Cao's mother: It was just in Shanghai. We were not good enough to get a ranking, so we didn't go to games outside Shanghai.

Dan Cao didn't make it to the International Special Olympics. He just participated in community-level games. Players for the International Special Olympics 
were selected from the community. Dan Cao's performance was not as good as others. We had to make sure that only the best ones got selected. So, five kids were selected from our community and Dan Cao got eliminated (giggles). I said, "No worries. He was never guaranteed a place just 'cos he's my kid, it's okay."

You have to be fair when you work for CAPIDR. For example, there was a calisthenics competition every year. I would always tell them, "If Dan Cao is not qualified, don't put him in just because of me." There would always be gifts if you go to competitions at the district or municipal level. Because of this, some leaders in other communities would send their own kids to such competitions, whether they were qualified or not. In my opinion, that would literally drag the team down and I didn't want that to happen. We would make sure that only the best ones in our community would be selected. This principle also applies to Dan Cao. If he was not good, he was disqualified. People respect me for that. They said, "Teacher Wang, you are very fair.” I replied, “I have to be. I won't squeeze my kid into the game just for the sake of some little gifts or benefits. I am not doing my job for that."

With no ranking he felt frustrated. His teacher told him, "It doesn't matter. Try harder next time." He said yes (giggles).

Q: Did he tell you about Special Olympics at home?

Cao's mother: Yes. He told me someone sweated a lot and he wiped tears off someone else's face.

Also, a kid tripped over because his shoelace was undone. Dan Cao helped him to get on his feet and dusted off his clothes. "I also comforted him, telling him not to cry," said Dan Cao.

In fact, he knows how to (help others). I often tell him that you guys need to help each other out. He remembers, and he knows what to do.

Q: Did he ever say it was tough and tiring and that he didn't want to go on anymore?

Cao's mother: No, he never said it was tough or tiresome. Sometimes he told me he was very excited. He liked this sport, thought it was fun.

I realized that he became more friendly when he was with his friends. He said, "Mom, I think it's a lot of fun when I am with them. We don't argue with each other." I said, "Right. Don't argue. You have to unite together (giggles)." I said that they have to be together like a family with no arguments (laughs).

Q: Has he enlarged his social circle? I mean, is he in contact with more people?

Cao's mother: Yes, we also want to help him to meet more people.

In fact, their circle is not big-it's rather small. They are only in contact with other people with mental disabilities. It is strange that they talk a lot more when they are with the same type of people and talk a lot less with normal people. He especially likes to spend time with his buddies at the Sunshine Home.

Actually, he likes to take the initiative in doing things. He likes to play with people of similar personalities. He likes to play with Cheng, Han, and Zheng at the Sunshine Home. However, there are also other types of kids at the Sunshine Home with whom he doesn't like to mingle. I just asked him about Lu. According to him, Lu is rather tricky, so he doesn't like to play with him.

Q: What do you parents think of Special Olympics?

Cao's mother: We think it is great. 
We are happy as long as the kids are happy. Don't you agree? We do everything for the sake of him.

I believe Special Olympics can change them. It is true. Had there been no Special Olympics, they wouldn't have experienced so much, right?

Q: Do you think there are any areas Special Olympics could improve on?

Cao's mother: I feel that Special Olympics could be made accessible to more people. Those kids who are even less competent... They should be given the opportunity to participate, too. I don't have many suggestions (giggles).

$\mathrm{Q}$ : Are there any other sports activities that you wish your kid could participate in?

Cao's mother: I actually want him to participate in every activity. In fact, everyone wants their kids to try things out.

Q: If he had the chance, would he take the initiative and participate in these activities, or would you be the one to push him to participate?

Cao's mother: He would like to participate. Eh, sometimes it's down to the Sunshine Home's choice. If you are not good enough, they won't let you participate.

\title{
Interview with Dan Cao's Teacher
}

\author{
Interviewee: Teacher A \\ Interviewer and writer: Zhang Di \\ Interview date: December 7, 2016 \\ Interview place: Sunshine Home of Jiaxing Subdistrict, Hongkou District, \\ Shanghai
}

Teacher: Our Sunshine Home is the most active in Hongkou District. There are volunteers from Monday to Friday, as well as tons of activities. The kids here are really happy. Over the past few years, our kids have all made progress-in the past they would lose their temper at home, but now they can control it. For example, if he is happy at the Sunshine Home in the morning, he will also be in a good mood when he gets home. Take Dan Cao as an example. In the past, he always needed his mom to bring him upstairs, but gradually his mom would only need to bring him to the entrance and would let him come up himself. Now, he only needs to be brought to the crossroad, and he can walk here himself. Anyways, they have all made huge progress.

Also, our Sunshine Home is together with the Sunshine Psychiatric Garden, so the supervision is relatively strict. Our parents have set up an Association of Family Members and Friends, which even includes our teachers like our dance teacher and Teacher Zhou. If the parents have any concerns, they may first turn to the Association, and we will try to solve any problems, if we can. This also helps our communication. There are no such organizations that are free of charge in other countries, so parents there need to pay a lot. 
Q: What do you think about Dan Cao's performance at the Sunshine Home? How does he get along with the other students?

Teacher: He does okay.

Dan Cao has severe intellectual disability. You may see that he cannot control his own actions. However, the progress is still huge. He previously came from the Children's Charity House where everyone there had severe intellectual disability. Technically he was not allowed to come here. People like him will only receive rehabilitation treatment. Students just take him as a little kid, because he doesn't understand a lot of things.

Q: How long has he been here?

Teacher: He came around $2007,{ }^{3}$ during Special Olympics. He could only learn how to bounce a ball at that time. Even today, he can still only bounce it several times.

Q: He knew how to bounce balls after Special Olympics? Are there any other changes?

Teacher: His self-care ability has improved a bit. Unlike at the beginning when he didn't know how to wash bowls or cups, he has learned how to do these things after coming here. We can teach him a little bit of self-care.

Previously, it could be that other people were communicating, but he just sat there without uttering a word. Now, although people can't understand him, they still talk to him.

Q: Does he show interest in any particular things?

Teacher: He just likes to talk. When you sing, he also follows you, and these are all okay. However, he can't sing by himself.

Q: Why did he not bring paint today?

Teacher: Well, when it comes to paint, he doesn't know how to deal with it. We can't even teach him. He should stay home because of his severe intellectual disability.

Q: I heard from his mom that he was taught to string beads, and he has learned a lot of hand-related activities.

Teacher: For stringing the beads, you just use one string and pass it through beads. He has learned how to do it now. Previously he could not pass the string through the beads, but he finally has mastered the skill. We had to teach him by holding his hands and helping him do the job. We have to repeatedly teach him, and let him practice over and over again. For him, he can only learn by practicing repeatedly.

Q: Is there anything about him that leaves a deep impression with you?

Teacher: He can now do some laboring work, and is willing to. In the past, he was not willing to move desks, chairs and such, and he even asked others to fill up his water bottle. When he needed water, he just demanded others by saying, "Help me fill this up," exactly like a prince, but now he can do it himself. He is talkative. His mouth was not sassy before, but now it is. This can also be regarded as an improvement, right?

\footnotetext{
${ }^{3}$ Dan Cao came to the Sunshine Home in 2005. He participated in the qualification tryouts and waist drum practices etc. before Special Olympics.
} 
Q: Did he have any arguments with his classmates? Based on his current condition he shouldn't have any major problems with his personality?

Teacher: It's just that... students with mental issues will tease him, and he will get mad. Sometimes he just attempts to fight back, but nothing else.

Q: Do you think he will stay long-term at the Sunshine Home?

Teacher: They can only stay at the Sunshine Home till they are 35 years old! If he can be like he is now in society, it is already pretty good. That is because his brain doesn't function well-if you ask him to do something, he will start to make noises. Can't do anything about it, because his brain can't control his actions and thoughts.

Q: In the future, he can basically only stay home or at the Children's Charity House?

Teacher: Yes, his parents have taught him things like how to sweep the floor, and that's all. You can't let him buy stuff with money, not possible. We can cook food or place the food on the table, but he can only pick the vegetable leaves. His hands are not able to do anything else.

\section{Interview with Dan Cao's Classmates}

Interviewees: Dan Cao's classmates

Interviewer and writer: Di Zhang

Interview date: December 7, 2016

Interview place: Sunshine Home of Jiaxing Subdistrict, Hongkou District, Shanghai

Q: Do you often communicate with Dan Cao?

Student 1: Sometimes we talk to him. It is just that he usually doesn't understand what we are saying. He is always like that, and he doesn't learn when we try to teach him. Sometimes he doesn't know the questions we ask him, so he simply does not answer.

Q: Are there any other things that he can do himself? Are there any aspects that are particularly good about him?

Student 1: His massages are very good. Back knocking and massage. He does back-knocking massage for our teachers. Yes, there are (good aspects). For example, he sometimes helps us girls. How to put it, it's a kind of feeling that is hard to describe. However, he can't do much, so at most we would let him give us a massage when we are sore.

Q: Does Dan Cao always sit by himself?

Student 1: Yes. I always have to go up to him to talk to him. Then he just gestures for me to take a seat in his room. I walk in, and he always finds me a seat even if I don't want one...

Q: Is there anything about him that leaves a deep impression?

Classmate 1: No... The only deep impression about him was that we let him bounce the ball, but he just couldn't do it. I learned how to bounce balls with him and 
another student who also didn't know how to bounce balls. The other student and I have both learned the skill, but not him. Also, it always takes the teacher forever to get him to bounce the ball. "Dan Cao, you have to bounce the ball!" He just bounces it several times and stops, and then the teacher has to tell him again so he would continue to bounce the ball. When the teacher is not looking at him, he would just leave. Later, the teacher would ask for him again, because he would just stand at the back, and the teacher doesn't know. Sometimes we ask him, "Dan Cao, what do you want to eat in the afternoon? You have to bounce the ball in order to eat." However, when the teacher is not paying attention to him, he just won't bounce the ball. I don't even know what's up with him.

Q: Are you good friends with Dan Cao? I see you guys holding hands, right?

Classmate 2: Yes, we are both in the same class. We play games together.

Dan Cao: Xiaomou Huang, his name is Xiaomou Huang. He is tall, very tall. You got me? This is my new classmate. Well, he is very nice, and he always plays with me.

Q: What do you often do when you are here?

Dan Cao: String beads and bounce balls. I bounce balls.

Q: Will he come up to you or teachers to say hi?

Classmate 1: Sometimes yes, but very rarely. We always have to say hi to him. He will only say "Good morning teacher," and "Bye." That's all.

Student 1: He always makes an old man in the Sunshine Psychiatric Garden fill up his water bottle, and has been caught by our teacher multiple times. I don't think this is appropriate. He knows how to do it, but he doesn't want to, so he asks others to help him. I always tell him to do it himself.

Classmate 3: He sometimes will, or classmates will help him to fill up his water bottle. He massages very well. You can even ask him.

Dan Cao: Massage, I always massage my mom.

Classmate 1: He gives great massages.

Classmate 3: I sometimes help him cut his nails.

Dan Cao: We are all classmates. Have to help each other.

\section{Interview with Dan Cao}

\section{Interviewee: Dan Cao}

Interviewer and writer: Di Zhang

Interview date: July 18, 2017

Interview place: Dan Cao's home

Q: Were you afraid of staying at home alone when you were young?

Dan Cao: Yes. There were mice, this big (illustrating the size with his thumb and forefinger). I was frightened to death. I was afraid that the mice would bite me. I was afraid of caterpillars, mice, cockroaches, a lot...

Q: Did you ever want your mom and dad to stay home and accompany you? 
Dan Cao: Yes! But they worked very hard, very busy, fully tied up. I was always at home, watching TV and playing games.

Q: Did you blame your mom and dad?

Dan Cao: No, how could I blame them? They were busy at work! What's more, Mom was always with me when I went to see a doctor or took medicine.

Q: Your grandpa didn't go to see you when you had surgery. How did you feel at that time?

Dan Cao: Sad. I cried, sad...I wanted to see him. How was his illness? I wanted to see this old man and take care of him...

Q: When Mom and Dad were not at home, you would watch TV alone. Did you want to go out and play with other children?

Dan Cao: Yes, very much. There was no place to go. How could I get out? No one would play with me. What should I do...

Q: Your mom mentioned that a guy once ate up your meal, you...

Dan Cao: I hate him. He ate up my meal. Unlucky, very sad. Isn't he a bad kid? I no longer play with him.

Q: Do you remember going to school? Which schools have you been to?

Dan Cao: Yes, the Children's Home...

Cao Mother: He certainly would not remember the elementary school, because he went there for only 1 month and then got rejected.

Dan Cao: Rejected. They did not want me. I stopped going to school.

Q: Do you like to go to school?

Dan Cao: Yes, how could I not like it. Too boring, and I could not concentrate during the class.

Q: Are you happy at the Sunshine Home? What do you do there?

Dan Cao: Yes. Walk there. Walk around and look around. Do some exercises. Handcraft work, singing, playing, playing cards, ball games, table tennis, wiser ball games, and so on.

Q: Do you still remember your participation in Special Olympics?

Dan Cao: Yes. I chose bowling, which is a very interesting ball game (hand showing a ball-gripping action). The ball rolls in and the bottles would fall.

Q: Did you find the balls heavy?

Dan Cao: Yes, very heavy, one kilo in weight, this big (hand gesture showing size). "Ping," you throw the ball over there and you make it!

Q: How was the training at that time?

Dan Cao: For bowling, first with bottles. We lined up on the training field to play one by one. Use your hand to get go with force. "Clatter"... you win when... fall.

The training of bowling was tough, very tough. I could hardly hold such a big ball and would drop it... Then I won. I practiced hard and I could finally hold the ball. I was not afraid of tough training nor did I feel tired. I was confident that I could accomplish the mission.

Q: Didn't you go to games out of the city?

Dan Cao: No, I was not chosen. No problem.

Q: Any other interesting activities that you took part in? 
Dan Cao: Waist drum, the waist drum team! "Rub-a-dub," playing the waist drum, so happy! A veteran player, among those who joined the team the earliest.

Q: How long did you receive training at that time?

Dan Cao: One year, one year and a half.

Q: Did you feel tired?

Dan Cao: Of course. I sweated a lot, and my waist felt sore and hurt. Such a long stick, and my hand felt too sore as a result of practice to hold it.

Q: Did you find it difficult to learn?

Dan Cao: Yes, you have to remember the new lessons, and you have to practice so that you could play it well. You have to. You have to play the whole (song).

The waist drum is this big (showing the size with hand gesture around the waist), and it is tied to your body by a red rope. All the players have to line up and I stand at the very front. You hit the drum once and then the team changes to $\mathrm{X}$ formation, and then you play the drum with T-shaped steps.

Q: What if you forgot what you'd learned?

Dan Cao: My hand would be hit by my mom, very painful.

Q: Did you ever think about giving it up?

Dan Cao: No way, I had to complete the task!

Q: Do you like playing the waist drum?

Dan Cao: Yes, I do. Playing waist drum (is) very happy. "Rub-a-dub," the sound is so pleasant to the ear! Very happy and it makes me feel proud.

Q: Then did you feel it more fun or more tiresome?

Dan Cao: More fun. In my heart (I feel very happy), the kids play the waist drums together, enjoying time together, jumping, enjoying themselves, how wonderful!

Q: Would you teach new players who couldn't play?

Dan Cao: Yes, or I would call teachers for help and..."Go to play."

Q: Do you still remember the opening ceremony of Special Olympics? Was it exciting? Were there many people?

Dan Cao: Yes, I remember and it was exciting. There were many people, and every one of us appeared in the performance. We ran onto the field. We were the first to perform. We ran forward and then "rub-a-dub," we started to play the drum.

Q: Do you think you played well in the performance?

Dan Cao: Yes.

Q: Do you want to take part in this kind of activity again? Do you want to take part in the Special Olympics Games again?

Dan Cao: Yes, of course! I do want to take part in it, but I have to play it well so that I could appear in the performance. It's a sports event, so things have to be done right. Have to be good. 


\title{
Observation of Dan Cao at the Sunshine Home
}

\author{
Observation date: 9:00-15:00, December 7, 2016 \\ Observation place: Sunshine Home of Jiaxing Subdistrict, Hongkou District, \\ Shanghai \\ Observer and writer: Di Zhang
}

\begin{tabular}{|c|c|c|}
\hline Time & Activity & Activity of the observed \\
\hline $8: 55$ & $\begin{array}{l}\text { Staff members } \\
\text { make } \\
\text { preparations in } \\
\text { advance }\end{array}$ & Watches at the side and greets other students \\
\hline $9: 00-9: 10$ & $\begin{array}{l}\text { Do the "Ninth Set } \\
\text { of Calisthenics to } \\
\text { Radio Music" } \\
\text { A parent } \\
\text { volunteer, who's } \\
\text { concurrently the } \\
\text { dance teacher, } \\
\text { guides the } \\
\text { students to do the } \\
\text { calisthenics; } \\
\text { students who } \\
\text { know how to do it } \\
\text { are put in the first } \\
\text { row to } \\
\text { demonstrate to } \\
\text { the rest together } \\
\text { with the teacher }\end{array}$ & $\begin{array}{l}\text { Dan Cao goes to his usual spot and looks at the students in } \\
\text { front of him. He stretches his hands and feet, and then } \\
\text { looks around again. When he has eye contact with others, } \\
\text { he immediately beams with a radiant smile } \\
\text { He stands at the very back. When others raise hands, he } \\
\text { raises his hands; when others stretch their bodies, he twists } \\
\text { his as well. Soon he is not able to keep up with the rhythm, } \\
\text { so he stretches out his arm or bends over at his own } \\
\text { rhythm. His actions are not coordinated, but are done in a } \\
\text { very serious manner. If he notices that someone is looking } \\
\text { at him, he would beam with his signature smile and show } \\
\text { his moves to them }\end{array}$ \\
\hline $9: 11-9: 20$ & $\begin{array}{l}\text { Joint Exercise of } \\
25 \text { Moves }\end{array}$ & $\begin{array}{l}\text { Dan Cao is still not up to the beat, so he moves at his own } \\
\text { will. Sometimes he can manage to keep up with the } \\
\text { teacher, but after a few moves, he would start to look at the } \\
\text { ground or at someone else. He cannot focus. When the } \\
\text { Joint Exercise is over, he quietly goes to get his coat by } \\
\text { himself and then stands at the side watching the teacher } \\
\text { teach a few students to dance. According to the teacher, } \\
\text { only a few students can join the dance rehearsal. Dan Cao } \\
\text { is not able to do these dance moves, so he doesn't } \\
\text { participate }\end{array}$ \\
\hline
\end{tabular}


(continued)

\begin{tabular}{|c|c|c|}
\hline Time & Activity & Activity of the observed \\
\hline $9: 20-9: 30$ & $\begin{array}{l}\text { The teacher } \\
\text { brings a few } \\
\text { students to play } \\
\text { table tennis, and } \\
\text { calls Dan Cao to } \\
\text { join }\end{array}$ & $\begin{array}{l}\text { Very happy and keeps smiling, though he is just standing } \\
\text { aside watching others } \\
\text { Starts to look around again } \\
\text { The teacher teaches him how to play. Mumbling "play } \\
\text { table tennis, I don't know how to play table tennis," he } \\
\text { takes the racquet handed over to him smiling } \\
\text { He cannot extend his arm very straight, and when the ball } \\
\text { comes he is not able to get it very well. The teacher holds } \\
\text { his hand to play. He is then able to get the ball a few times. } \\
\text { He is very happy } \\
\text { After playing a few rounds, he decides to get off the court } \\
\text { and stand to the side watching the teachers play } \\
\text { He looks around, and suddenly stares at the edge of the } \\
\text { wall. Then he picks up a string of wool. He wipes the dust } \\
\text { on the wool like a little kid and then puts the wool back }\end{array}$ \\
\hline $9: 30-10: 15$ & $\begin{array}{l}\text { Seven or eight } \\
\text { students are still } \\
\text { rehearsing the } \\
\text { dance with the } \\
\text { teacher, and the } \\
\text { teacher asks Dan } \\
\text { Cao to watch } \\
\text { them. Dan Cao } \\
\text { stands at the back } \\
\text { with other } \\
\text { students, } \\
\text { watching }\end{array}$ & $\begin{array}{l}\text { He is able to listen and follow the teacher, and stands there } \\
\text { without moving randomly } \\
\text { Talks with another student from time to time. The } \\
\text { conversation is started by the other student and they are } \\
\text { discussing the thickness of their coats } \\
\text { Dan Cao shows his coat to the other student, and says } \\
\text { repeatedly, "Wool, thick, not cold..." The other student } \\
\text { tries to warm his hands by putting them at the side of Can } \\
\text { Dan's coat. Dan Cao shows no objection and they continue } \\
\text { to talk from time to time } \\
\text { Seeing that I'm writing, he asks me simple questions like } \\
\text { "What are you writing? Why are you taking pictures?" He } \\
\text { would take the initiative to talk to people he knows. Also, } \\
\text { he would point his fingers at dancers to signal people to } \\
\text { watch their dances } \\
\text { He watches the dance quietly, and would occasionally } \\
\text { come up with a topic for conversation, but only with a } \\
\text { fixed group of students. Their conversation has been } \\
\text { centering around "whether your coat is thick or not". He } \\
\text { would always show his coat to others and would smile } \\
\text { whenever there's eye contact with others. He rarely chips } \\
\text { in when there's a large group of people talking }\end{array}$ \\
\hline $10: 15-10: 20$ & $\begin{array}{l}\text { The other } \\
\text { students finished } \\
\text { rehearsing. Time } \\
\text { for recess }\end{array}$ & $\begin{array}{l}\text { He takes his water bottle to get some water to drink, and } \\
\text { then stands there with his bottle }\end{array}$ \\
\hline
\end{tabular}


(continued)

\begin{tabular}{|c|c|c|}
\hline Time & Activity & Activity of the observed \\
\hline $10: 20$ & $\begin{array}{l}\text { The desks and } \\
\text { chairs need to be } \\
\text { returned to their } \\
\text { original positions }\end{array}$ & $\begin{array}{l}\text { He takes the initiative to help move chairs and desks. He is } \\
\text { excited that he is able to help and tries to gather other } \\
\text { students when walking, "Come on!" } \\
\text { He is enjoying the work. He starts to run and appears to be } \\
\text { very active } \\
\text { Another student needs to move a desk. Dan Cao puts down } \\
\text { his chair, and immediately turns around to help. The two } \\
\text { of them lift the table together and place it in the } \\
\text { appropriate spot. He rarely talks to the other student during } \\
\text { the process but is very enthusiastic }\end{array}$ \\
\hline 10:25 & $\begin{array}{l}\text { Dan Cao watches } \\
\text { other students } \\
\text { playing table } \\
\text { tennis }\end{array}$ & $\begin{array}{l}\text { Would talk to other students, and is in a very good mood } \\
\text { When the players do well, he would praise them by giving } \\
\text { them a thumbs-up }\end{array}$ \\
\hline $10: 37$ & $\begin{array}{l}\text { Lunch is } \\
\text { delivered to the } \\
\text { classroom, and } \\
\text { everyone is ready } \\
\text { to eat }\end{array}$ & $\begin{array}{l}\text { He follows the teacher's instruction to get his bowl and } \\
\text { chopsticks ready for lunch. However, he seems a little } \\
\text { nervous now and stands aside waiting when there are only } \\
\text { a few students taking the food } \\
\text { He gets his spoon. There aren't many students taking the } \\
\text { food, so he stands silently not too far away and quietly } \\
\text { watches } \\
\text { When there are more students going to take the food, he } \\
\text { goes up to get some } \\
\text { He sits down in the last row. After he places his food on } \\
\text { the table, he waits in the line to get soup }\end{array}$ \\
\hline 10:45 & Lunch time & $\begin{array}{l}\text { Eats the food by himself, brings his lunchbox to the } \\
\text { teacher, and washes the spoon }\end{array}$ \\
\hline 12:00-13:55 & Recess & $\begin{array}{l}\text { Communicates with friends, and gets ready for an } \\
\text { afternoon nap } \\
\text { Takes his coat and blanket and rests on a few chairs }\end{array}$ \\
\hline 14:00 & $\begin{array}{l}\text { After recess, time } \\
\text { for class }\end{array}$ & $\begin{array}{l}\text { Puts away his own coat and stuff } \\
\text { Doesn't put on the clothes previously taken off }\end{array}$ \\
\hline 14:00 & $\begin{array}{l}\text { Art lesson: The } \\
\text { Secret of Colors }\end{array}$ & $\begin{array}{l}\text { Dan Cao sits at the desk in the second last row beside the } \\
\text { wall near the window. Before the lesson begins, he puts } \\
\text { blank paper, pen and pencil case on the desk, and sits still } \\
\text { with a pencil in his hand } \\
\text { He stands up with the other students at the beginning of the } \\
\text { class and they chorus "I know I can." He can't speak very } \\
\text { clearly, but he knows to participate } \\
\text { After clapping hands, he sits down and flips his blank } \\
\text { paper over and over again. He lets the observer look at his } \\
\text { stationery, pulls out an origami that he made himself and } \\
\text { says to me, "Take it away." }\end{array}$ \\
\hline
\end{tabular}


(continued)

\begin{tabular}{|c|c|c|}
\hline Time & Activity & Activity of the observed \\
\hline 14:02 & $\begin{array}{l}\text { The teacher asks } \\
\text { everyone to bring } \\
\text { a rock to the next } \\
\text { class for color } \\
\text { painting }\end{array}$ & $\begin{array}{l}\text { He is able to understand the teacher's words and keeps } \\
\text { repeating "I need to bring a rock." } \\
\text { The other students ask the teacher about any other } \\
\text { requirements, but he doesn't communicate with others }\end{array}$ \\
\hline 14:05 & $\begin{array}{l}\text { The teacher starts } \\
\text { the lesson }\end{array}$ & $\begin{array}{l}\text { He sits upright in his seat with his hands around his chest, } \\
\text { looking around-seems to be attentive to the lesson } \\
\text { Someone passes by the walkway, and his eyes follow him. } \\
\text { When the teacher interacts with the students, he can } \\
\text { respond, but he only talks to himself without effective } \\
\text { interaction with others } \\
\text { His eyes won't stay on the teacher's actions for more than } \\
1 \text { min }\end{array}$ \\
\hline 14:09 & $\begin{array}{l}\text { The teacher asks } \\
\text { students to draw } \\
\text { two balls of the } \\
\text { same size }\end{array}$ & $\begin{array}{l}\text { He does not draw anything, but sits there and stares at the } \\
\text { teacher instead } \\
\text { He starts to fiddle with the flowers on the windowsill } \\
\text { Other students are able to find tools such as coins or use } \\
\text { the bottom of water bottles to draw two circles. However, } \\
\text { he does not move his hands. I don't know why, but all the } \\
\text { students have paint except him. He just silently watches } \\
\text { others paint }\end{array}$ \\
\hline 14:14 & Drawing & $\begin{array}{l}\text { He watches the student next to him draw. The teacher is } \\
\text { guiding that student on the next step. With a pencil in his } \\
\text { right hand, Dan Cao stares at the blank paper in front of } \\
\text { him, but apparently he is not in the mood for drawing. He } \\
\text { does not put his pencil to paper }\end{array}$ \\
\hline $14: 20$ & $\begin{array}{l}\text { The teacher is } \\
\text { helping others }\end{array}$ & $\begin{array}{l}\text { His eyes follow the teacher and he flips the blank piece of } \\
\text { paper in front of him. Sitting next to him is the student he } \\
\text { mentions a lot, but still, he doesn't take the initiative to talk } \\
\text { with him } \\
\text { When someone asks a question, he would turn his head } \\
\text { and look towards that direction }\end{array}$ \\
\hline $14: 30$ & $\begin{array}{l}\text { The teacher gives } \\
\text { a simple } \\
\text { instruction asking } \\
\text { students to stop }\end{array}$ & $\begin{array}{l}\text { He puts down his pencil, but unlike other students, he } \\
\text { doesn't talk }\end{array}$ \\
\hline $14: 32$ & $\begin{array}{l}\text { The teacher } \\
\text { explains the } \\
\text { flavors that } \\
\text { different colors } \\
\text { represent } \\
\text { With } 23 \text { students } \\
\text { in the class, the } \\
\text { teacher is not able } \\
\text { to give enough } \\
\text { attention to Dan } \\
\text { Cao }\end{array}$ & $\begin{array}{l}\text { He hears other students talk and repeats some words } \\
\text { himself, such as "bitter coffee" and "lemon, sour." }\end{array}$ \\
\hline
\end{tabular}


(continued)

\begin{tabular}{l|l|l}
\hline Time & Activity & Activity of the observed \\
\hline $14: 36$ & $\begin{array}{l}\text { The teacher } \\
\text { explains the } \\
\text { flavors that } \\
\text { different colors } \\
\text { represent }\end{array}$ & $\begin{array}{l}\text { He keeps repeating things based on common sense in his } \\
\text { daily life. He also talks to himself with no intent to } \\
\text { communicate with others } \\
\text { Some students look at him, and he smiles back as a } \\
\text { response } \\
\text { When students in the rows behind him call his English } \\
\text { name "Mark," he immediately responds to the }\end{array}$ \\
\hline $14: 40$ & $\begin{array}{l}\text { The teacher } \\
\text { explains the } \\
\text { flavors that } \\
\text { different colors } \\
\text { represent }\end{array}$ & $\begin{array}{l}\text { Finally, he grabs a pencil and draws a straight line } \\
\text { When he hears other students say something wrong, he } \\
\text { would correct them; for instance, telling them that "lemons } \\
\text { are sour." However, he doesn't make eye contact with } \\
\text { anyone. He just faces the front and he would not take the } \\
\text { initiative to start a conversation }\end{array}$ \\
\hline $14: 43$ & $\begin{array}{l}\text { Other students are } \\
\text { cleaning up for } \\
\text { the art class }\end{array}$ & $\begin{array}{l}\text { He draws a rectangle and a few horizontal lines (copying } \\
\text { the pattern of the observer's notebook) } \\
\text { He looks around again }\end{array}$ \\
\hline End of class & $\begin{array}{l}\text { Stands up and claps his hands } \\
\text { after class }\end{array}$ & $\begin{array}{l}\text { He organizes his pen and paper, and enters another room to } \\
\text { get his bag. Then he sits at his desk, waiting for his dad to } \\
\text { pick him up } \\
\text { A student comes up to talk to him, and he starts to } \\
\text { communicate with them } \\
\text { He walks with a student in the classroom }\end{array}$ \\
\hline $15: 03$ & $\begin{array}{l}\text { Waiting for } \\
\text { parents to pick up }\end{array}$ & $\begin{array}{l}\text { When he hears other students say bad things about him, his } \\
\text { mood suddenly becomes bad } \\
\text { However, he is instantly happy again when a student } \\
\text { mentions he is good at back-knock massage }\end{array}$ \\
\hline $15: 10$ & &
\end{tabular}

Translated by Zheng Si. Edited by Andy Boreham and Zijian Chen.

Open Access This chapter is licensed under the terms of the Creative Commons AttributionNonCommercial-NoDerivatives 4.0 International License (http://creativecommons.org/licenses/bync-nd/4.0/), which permits any noncommercial use, sharing, distribution and reproduction in any medium or format, as long as you give appropriate credit to the original author(s) and the source, provide a link to the Creative Commons license and indicate if you modified the licensed material. You do not have permission under this license to share adapted material derived from this chapter or parts of it.

The images or other third party material in this chapter are included in the chapter's Creative Commons license, unless indicated otherwise in a credit line to the material. If material is not included in the chapter's Creative Commons license and your intended use is not permitted by statutory regulation or exceeds the permitted use, you will need to obtain permission directly from the copyright holder.

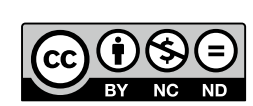

